\title{
Nanomaterials Based Drinking Water Purification: Comparative Study with a Conventional Water Purification Process
}

\author{
Barış Şimşek ${ }^{1 *}$, Inci Sevgili1,2, Özge Bildi Ceran¹, Haluk Korucu¹, Osman Nuri Şara ${ }^{3}$ \\ ${ }^{1}$ Department of Chemical Engineering, Faculty of Engineering, Çankırı Karatekin University, 18120, Çankırı, Turkey \\ 2 Çankırı Municipals, Water and Service Association, 18100, Çankırı, Turkey \\ ${ }^{3}$ Department of Chemical Engineering, Faculty of Natural Sciences, Architecture and Engineering, Bursa Technical University, \\ 16310, Bursa, Turkey \\ *Corresponding author, e-mail: barissimsek@karatekin.edu.tr
}

Received: 25 April 2018, Accepted: 02 July 2018, Published online: 17 July 2018

\begin{abstract}
One of the ways of fully securing the presence of fresh water is water treatment process. Nanomaterials and nanotechnology offers an innovative solution for water treatment. In this study, physical, chemical and microbiological improvement rates of raw water were analyzed after filtration with graphene oxide. Graphene oxide's water treatment performance; silver nanoparticles, silver nanoparticles \& graphene oxide composites that are commonly used in water treatment were compared with a traditional treatment method. When compared to the traditional method, there were improvements of $50 \%, 40.7 \%, 86.8 \%$ and $45.5 \%$ for color, TIC, TOC and hardness properties, respectively in water treatment by GO-based filtration with solid liquid ratio of $0.7 \%$ (v/v). In water treatment with GO-Ag based filtration, $39.8 \%, 69.8 \%, 10.3 \%$ and $28.6 \%$ of improvements were obtained for TIC, TOC, hardness and $\mathrm{LSI}$ value compared to the conventional method. Both GO at $0.7 \%(\mathrm{v} / \mathrm{v})$ solid-liquid ratio and GO-Ag nanocomposites were successful in the number of total viable microorganisms and inhibiting microorganisms such as Escherichia coli fecal (gaita-infected), Salmonella typhi, Enterococcus faecalis, Pseudomona aeruginosa and Staphylococcus aureus. Among the studied parameters GO-Ag nanocomposites found to be the most suitable for drinking water treatment.
\end{abstract}

\section{Keywords}

graphene oxide (GO), silver nanoparticles (AgNPs), graphene oxide-silver nanoparticles nano composites (GO-Ag), water purification, product design

\section{Introduction}

The fresh water scarcity and water pollution problem have been increasingly growing worldwide in the last several years [1]. It is estimated that two thirds of the world's population may have difficulties accessing healthy water by 2025 [2]. Nanomaterials and nanotechnology emerge as the best possible solution for drinking water disinfection [3-7]. Graphene oxide [1, 8-11], silver nano particles [12-15] and silver nanoparticles-graphene oxide nanocomposites [11] can be listed as the most prominent nano materials in water treatment [2].

Silver nanoparticles have been found to be effective in preventing the reproduction of microorganisms such as Escherichia coli (E. coli) [16], Staphylococcus aureus (S. aureus), Aspergillus flavus (A. flavus) [17], Enterococcus faecalis (E. faecalis) and Pseudomonas aeruginosa ( $P$. aeruginosa) [13] graphene oxide has been found to be effective in preventing the reproduction of microorganisms in water such as Enterococcus faecium (E. faecium), S. aureus and P. aeruginosa [18] whereas graphene oxide-silver nanoparticles composites have been found to be effective in preventing the reproduction of microorganisms in water such as E. coli [11], $S$. aureus [19, 20], P. aeruginosa [21], Candida albicans (C. albicans), Lactobacillus acidophilus (L. acidophilus), Streptococcus mutans (S. mutans) and Aggregatibacter actinomycetemcomitans (A. actinomycetemcomitans) [22], Bacillus subtilis (B. subtilis) [19].

In addition to its natural flora, water may contain microorganisms found in soil and plants, and in case of contamination it may contain microorganisms found in 
faeces and sewage waters. No matter what purpose water is used, it should not contain pathogenic microorganisms. There might be the bacteria belonging to the genus Pseudomonas, Chromo bacterium, Proteus, Micrococcus, Bacillus, Clostridium, Fecal Streptococcus, Enterobacter and Escherichia in waters. Water is also a major source of microorganisms that cause gastroenteritis in humans. It is known that microorganisms such as Salmonella, Shigella, and Vibrio cholera infaecally contaminated water cause intestinal infections and microorganisms such as Salmonella typhi and Salmonella paratyphi cause typhoid and paratyphoid outbreaks.

Poor water quality causes diarrhoeal deaths of 1.7 million people worldwide (which account for $3.1 \%$ of all deaths) annually. It is reported that $90 \%$ of this ratio is made up of children in developing countries [23-26]. In Alamosa, Colorado, drinking water contaminated with $S$. typhimurium caused to an epidemic in 2008, with this epidemic, $21 \%$ of the neighboring houses suffered from diarrhea and $29 \%$ of them had to deal with potential lifelong health problems. The cost of a waterborne Salmonella outbreak was estimated at about \$ 1.5 million, and people lost confidence in city water [27]. For this reason, securing city waters become more of an issue and the water treatment process come to the fore as the most powerful technique applied for this purpose.

Unlike studies in the literature, this study aims to analyze microorganisms such as E. coli, S. aureus, E. faecium, and $P$. aeruginosa as well as $S$. typhi, which also causes serious health problems in humans and get information about the inhibition of those from raw water with graphene oxide, silver nanoparticles, and silver nanoparticles-graphene oxide nanomaterials. Therefore, the anti-bacterial effect and the effect on the total number of viable bacteria (the medium that determines the presence of all bacteria) of graphene oxide, silver nanoparticles and silver nanoparticles \& graphene oxide nanocomposites on E. coli, E. faecalis, S. typhimurium, P. aeruginosa, S. aureus, E-coliform (Citrobacter freundii, Enterobacter aerogenes, Enterobacter cloacae, E. coli and Klebsiella pneumoniae) were studied for the first time in literature.

Graphene oxide is used especially for the purpose of removal of salts from water [28, 29], removal of metal ions [30, 31], removal of turbidity [32] while silver nanoparticles are used for the purpose of reducing the amount of total [33] and undissolved [34] organic carbon.

Unlike studies in the literature, this study aims to analyze the physical, chemical and microbiological properties of raw water taken from a dam such as temperature, $\mathrm{pH}$, alkalinity, conductivity, dissolved $\mathrm{O}_{2}$, turbidity, color, iron, manganese, nitrate, nitrite, ammonia, sulphite, total carbon, total organic carbon (TOC), total inorganic carbon (TIC), French hardness, calcium carbonate hardness, calcium, Langelier saturation index (LSI), E. faecalis, $S$. typhimurium, P. aeruginosa, S. aureus, E. coli, E-coliform and the total viable count water and improve these values to drinking water standards using graphene oxide, silver nanoparticles and silver nanoparticles \& graphene oxide materials. These quality criteria has been selected taking into account Turkish standard (TS) 266 prepared for water intended for human consumption [35].

\section{Materials and Method}

\subsection{Materials}

Graphite $(<50 \mu \mathrm{m})$, sulphuric acid (95-97\%), orthophosphoric acid (85\%), potassium permanganate (7-9 $\mathrm{pH})$, sodium hydroxide pellets $(\mathrm{NaOH},>99 \%)$, silver nitrate $\left(\mathrm{AgNO}_{3},>99.8 \%\right), \mathrm{D}(+)$ - Glucose anhydrous and extra pure starch soluble are supplied from Merck Millipore.

\subsection{Methodology}

There are 6 flow steps in the determination of the water purification performance of GO (Fig. 1). Firstly; the physical, chemical and microbiological properties have been determined as the quality criteria of raw and purified water with GO based filtration membrane synthesis process. Graphene oxide powders were synthesized by improved Hummers method and characterized by FTIR (FourierTransform Infrared Spectroscopy), Raman, (Atomic force microscopy) AFM and X-Ray Diffraction (XRD). Eight GO dispersions have been prepared to 0.1-0.8 \% (v/v). The raw and treated water performances for each experimental run were analyzed physically, chemically and microbiologically. Then, the water treatment performance of graphene oxide was compared with those of other commonly used AgNPs and GO-Ag nanomaterials. Finally, the water treatment performance of nanomaterials was compared with that of classical treatment methods in terms of physical, chemical and microbiological properties.

\section{Identification of the Water Purification Performance Conditions}

\subsection{Experimental conditions}

The raw water used in the study belongs to the dam such a surface water located in Çankırı Province. The dam has an occupancy rate of approximately $60 \%$. The dam water 


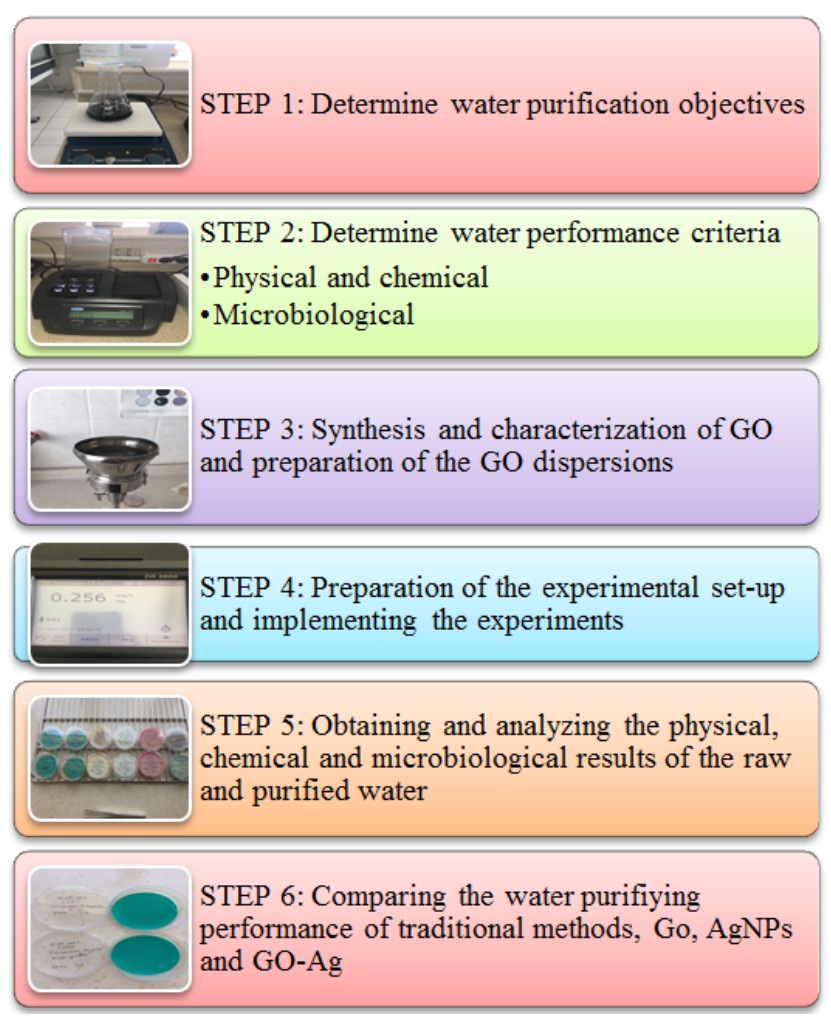

Fig. 1 Offered water purified performance analysis framework is transported to the water treatment plant by a pipeline 5 $\mathrm{m}$ below the surface. The water, which is carried from the dam, comes out from the raw water pool. A 5-liter sample was taken from the raw water pool and each experiment was treated with a membrane filtration system. Physical and chemical quality criteria for drinking water have been determined based on TS 266 (Waters-Waters for Human Consumption) and measurement techniques are shown in Table 1 [35].

Microbiological analysis of the water samples passed through the graphene oxide-coated filter was performed by membrane filtration technique [33]. Microbiological analyses were carried out using selective medium according to the standards shown in Table 2 in accordance with the Turkish Standards Institute [35]. Unfiltered raw water was used as a control experiment, and analyses were performed in comparison with the control experiment to observe the effect of antimicrobial agents (graphene oxide used).

\subsection{Synthesis of Nano-materials}

Synthesis of GO: The improved Hummers method has been selected to synthesize the graphene oxide samples

Table 1 Physical and chemical properties of drinking water according to TS 266

\begin{tabular}{|c|c|c|c|c|c|}
\hline No. & Quality criteria & Units & Standard (TS 266) & Measurement techniques & Target value \\
\hline 1 & Temperature & ${ }^{\circ} \mathrm{C}$ & $12.0-25.0$ & Thermometer & $12.0-25.0$ \\
\hline 2 & $\mathrm{pH}$ & $\mathrm{Ph}$ & $6.5-8.5$ & $\mathrm{pH}$ meter & $7.5-8.5$ \\
\hline 3 & Alkalinity & $\mathrm{mg} / 1$ & N/A & Titration & $80-120$ \\
\hline 4 & Conductivity & $\mu \mathrm{S} / \mathrm{cm}$ & $<2500$ & Conductivity meter & $200-250$ \\
\hline 5 & Dissolved $\mathrm{O}_{2}$ & $\mathrm{O}_{2} \mathrm{mg} / 1$ & $3-8$ & $\mathrm{O}_{2}$ & $7-10$ \\
\hline 6 & Turbidity & NTU & $0.4-1.0$ & Turbidity meter & $0.10-0.60$ \\
\hline 7 & Color & $\mathrm{Pt}-\mathrm{Co}$ & $1-20$ & Calorimetric & $0-4$ \\
\hline 8 & Iron & Fe mg/l & $0.05-0.2$ & Spectrophotometer & $0.00-0.15$ \\
\hline 9 & Manganese & $\mathrm{Mn} \mathrm{mg} / 1$ & $0.02-0.05$ & Spectrophotometer & $0.01-0.038$ \\
\hline 10 & Nitrate & $\mathrm{NO}_{3} \mathrm{mg} / 1$ & $<44$ & Spectrophotometer & $<44$ \\
\hline 11 & Nitrite & $\mathrm{NO}_{2} \mathrm{mg} / 1$ & $<0.1$ & Spectrophotometer & $<0.1$ \\
\hline 12 & Ammonia & $\mathrm{NH}_{3} \mathrm{mg} / \mathrm{l}$ & $<0.5$ & Spectrophotometer & $<0.2$ \\
\hline 13 & Sulphite & $\mathrm{mg} / 1$ & $0-250$ & Spectrophotometer & $<0.1$ \\
\hline 14 & $\mathrm{TC}$ & $\mathrm{mg} / 1$ & $12-75$ & Spectrophotometer & $12-75$ \\
\hline 15 & TIC & $\mathrm{mg} / 1$ & $10-73$ & Spectrophotometer & $10-73$ \\
\hline 16 & TOC & $\mathrm{CO}_{2} \mathrm{mg} / 1$ & $2-65$ & Spectrophotometer & $2-65$ \\
\hline 17 & French hardness & $\mathrm{F}^{0}$ & $\begin{array}{c}\text { 7.2-14.5 Soft } \\
\text { 14.5-21.5 Lightsoft }\end{array}$ & Spectrophotometer & $7.2-20$ \\
\hline 18 & Hardness & $\mathrm{CaCO}_{3} \mathrm{mg} / 1$ & 500 & Spectrophotometer & $<120$ \\
\hline 19 & Calcium & $\mathrm{mg} / 1$ & 200 & Spectrophotometer & 200 \\
\hline 20 & LSI & $\mathrm{HO}_{3} \mathrm{mg} / 1$ & $(-1 \leq \mathrm{LSI} \leq 1.0)$ & Spectrophotometer & $0.5-2.0$ \\
\hline
\end{tabular}


Table 2 Microbiological characteristics of raw water and drinking water

\begin{tabular}{|c|c|c|c|c|}
\hline No. & $\begin{array}{l}\text { Quality criteria } \\
\text { (Characteristic) }\end{array}$ & $\begin{array}{l}\text { Incubation } \\
\text { Conditions }\end{array}$ & $\begin{array}{l}\text { Parametric value } \\
\text { (number / } 100 \mathrm{ml} \text { ) }\end{array}$ & Application standard \\
\hline 1 & Total viable bacteria count (STANDART TTC NKS) & $30 \pm 2{ }^{\circ} \mathrm{C} / 2-5$ Days & $<100$ & TS ISO 21527-1 \\
\hline 2 & E-colifecal (MFC NKS) & $36 \pm 2{ }^{\circ} \mathrm{C} / 20+4$ Hours & 0 & TS EN ISO 9308-1 \\
\hline 3 & E. faecalis (AZİDE NKS) & $36 \pm 2{ }^{\circ} \mathrm{C} / 44+4$ Hours & 0 & TS EN ISO 7899-2 \\
\hline 4 & S. typhimurium (BİSMUTH SÜLFİTE NKS) & $36 \pm 2{ }^{\circ} \mathrm{C} / 48$ Hours & $0 / 100 \mathrm{ml}$ & TS EN 6579 \\
\hline 5 & P. aeruginosa (CETRİMİDE NKS) & $37 \pm 1{ }^{\circ} \mathrm{C} / 48+4$ Hours & $0 / 250 \mathrm{ml}$ & TS EN ISO 16266 \\
\hline 6 & S. aureus (CHAPMAN NKS) & $36 \pm 2{ }^{\circ} \mathrm{C} / 3$ Days & $0 / 100 \mathrm{ml}$ & EN 6888-3 \\
\hline 7 & E. coli & $36 \pm 2{ }^{\circ} \mathrm{C} / 21+3$ Hours & 0 & TS EN ISO 9308-1 \\
\hline
\end{tabular}

as following steps [36-38]: graphite $(3 \mathrm{~g})$, sulfuric acid $(69 \mathrm{ml})$ were added into a $1000 \mathrm{ml}$ reactor which was kept at $5{ }^{\circ} \mathrm{C}$ under continuous stirring for $15 \mathrm{~min}$ via cooled-circulating water [36-38]. Then, potassium permanganate $(9 \mathrm{~g})$ was slowly added into the mixture and stirred at $5{ }^{\circ} \mathrm{C}$ for $2 \mathrm{~h}$ and then, the reaction temperature was gradually raised to $35^{\circ} \mathrm{C}$. The mixture was stirred at $35^{\circ} \mathrm{C}$ for $30 \mathrm{~min}$ and $150 \mathrm{ml}$-deionized water was added to the suspension and the reaction temperature was raised to $98^{\circ} \mathrm{C}$ as a result of the hydration heat [36-38]. The oxidation process was terminated by adding $146 \mathrm{ml}$-deionized water and hydrogen peroxide $(30 \% \mathrm{v} / \mathrm{v}, 10 \mathrm{ml})$. Yellowish / brown color product was separated by vacuum filtration and the powders were washed at five times with the diluted hydrochloric acid solution $(5 \%, 100 \mathrm{ml})$ in order to remove metal ions. Lastly, these powders were dried at $60{ }^{\circ} \mathrm{C}$ into an oven for $12 \mathrm{~h} \mathrm{[36-38].}$

Synthesis of AgNPs: Firstly, $0.2 \%$ of the starch solution is dissolved at the $75{ }^{\circ} \mathrm{C}$ for 15 minutes in $40-\mathrm{ml}$ ultrasonic bath. $10 \mathrm{ml}$ from $0.001 \mathrm{M} \mathrm{AgNO}_{3}$ solution is added to the mixture and it is mixed for 10 minutes. The glucose is added to the mixture at an amount which is determined from $0.1 \mathrm{M}$ glucose solution depending on $2.5 \mathrm{AgNO}_{3} /$ glucose ratios. The mixture's $\mathrm{pH}$ is adjusted at 11.5 values using $0.1 \mathrm{M} \mathrm{NaOH}$ solution [39]. In this way, the silver nano particles has been obtained after continuous stirring for 1 hour at $75{ }^{\circ} \mathrm{C}$ [39].

Synthesis of GO-AgNPs composites: $2 \mathrm{mg}$ of graphene oxide is added to $50 \mathrm{ml}$ of distilled water and a stable dispersion is obtained by mixing in an ultrasonic bath for 2 hours. The obtained stable GO dispersion is added to the $10 \mathrm{ml}$ from $0.001 \mathrm{M} \mathrm{AgNO}_{3}$ solution (A). The starch solution $(0.2 \%)$ is dissolved at the $75{ }^{\circ} \mathrm{C}$ for 15 minutes in 40-ml ultrasonic bath and the glucose is added to the mixture at an amount which is determined from $0.1 \mathrm{M}$ glucose solution depending on $2.5 \mathrm{AgNO}_{3}$ / glucose ratios (B). $\mathrm{B}$ was slowly added to the $\mathrm{A}$ under magnetic stirring and the mixture temperature was fixed at $75{ }^{\circ} \mathrm{C}$ for $4 \mathrm{~h}$. The color of mixture changed from dark brown to green [39-41].

\subsection{Characterization of Nano-materials}

The characterization of the synthesized graphene oxide via FTIR spectroscopy was depicted at Fig. 2(a). The absorption band at $3364 \mathrm{~cm}^{-1}$ indicates that the presence of oxygen which contains groups $(\mathrm{O}-\mathrm{H}$ stretching vibrations). The absorption peak at $1714 \mathrm{~cm}^{-1}$ and $1618 \mathrm{~cm}^{-1}$ can be designated to $\mathrm{C}=\mathrm{O}$ stretching of carboxylic and/or carbonyl moiety functional groups. The two absorption peaks at about $1222 \mathrm{~cm}^{-1}$ and $1046 \mathrm{~cm}^{-1}$ are designated to the C-O hydroxyl and epoxy groups stretching vibrations, respectively [37, 38, 42]. Lastly, $579 \mathrm{~cm}^{-1}$ which corresponds to the epoxy (C-O-C) stretching mode which is located on the basal plane of graphene oxide. FTIR's results proved that the synthesis of graphene oxide by improved Hummers method was achieved for the each experimental runs [37, 38, 42].

AFM images can be used to characterize the surface morphology properties of graphene oxide such as average surface roughness, prediction of the thickness deviation and analyzing the surface morphology $[37,38]$.

In order to obtain average surface roughness via ezAFM device, the graphene oxide solutions were formed with acetone and then, all the graphene oxide solution was coated on the glass, and AFM analysis was performed $[37,38]$. The average surface roughness was calculated as $44.94 \mathrm{~nm}$ with the use of ezAFM device for a $5 \mu \mathrm{m} \times 5 \mu \mathrm{m}$ sample area (Fig. 2(b)).

Raman's spectroscopy is quite a useful tool to characterize graphene based materials $[37,38]$. The Raman's spectra of the graphene oxide samples shows two apparent peaks at positions around the $\mathrm{D}$ and $\mathrm{G}$ bands of pristine graphite with differences in position and relative intensity $[37,38]$. The Raman's spectrum of graphene oxide samples which was synthesized for water purification 


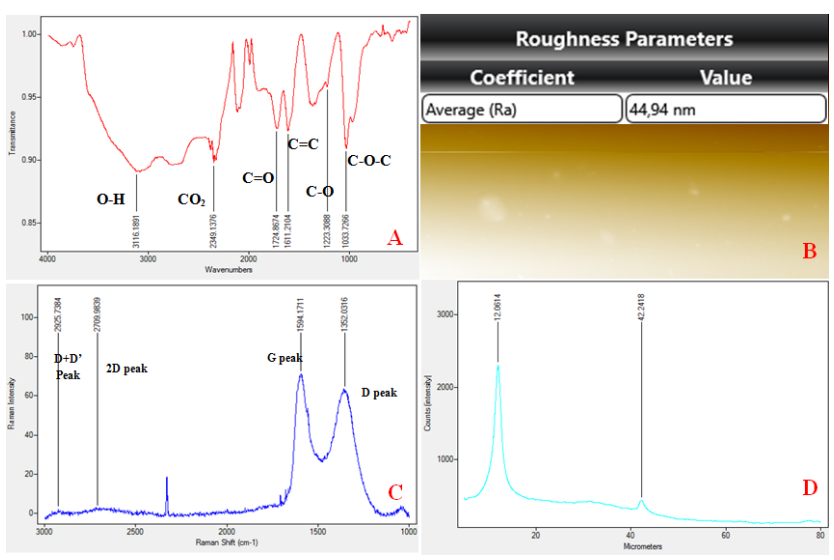

Fig. 2 Characterization of GO (a) FTIR, (b) AFM, (c) Raman spectroscopy and (d) XRD analysis

illustrates a G-band at $1590 \mathrm{~cm}^{-1}, \mathrm{D}$ band at $1350 \mathrm{~cm}^{-1}, 2 \mathrm{D}$ and D + D' band at $2700 \mathrm{~cm}^{-1}$ and $2930 \mathrm{~cm}^{-1}$, respectively (Fig. 2(c)). The excitation wavelength and the excitation leaser energy were selected as $785 \mathrm{~nm}$ and $10 \mathrm{mV}$, respectively $[37,38]$. Raman's results also demonstrate that the synthesis of graphene oxide with improved Hummers method was succeeded (Fig. 2(c)) [43].

The X-Ray diffractograms (XRD) of the graphene oxide samples show an apparent highly diffraction peak at about $9^{\circ}$ to $13^{\circ},(002)$ plane of graphene oxide and a diffraction peak at around $42^{\circ},(100)$ plane of graphene oxide, respectively [37, 38]. Graphene oxide samples which were used for water purification exhibit a diffraction peak at about $10^{\circ}$ and $13^{\circ}$ and another diffraction peak at around $42^{\circ}$ [36-38]. XRD's results also proved that the synthesis of graphene oxide by improved Hummers method was achieved successfully (Fig. 2(d)) [36-38].

A Perkin-Elmer UV-Visible spectrophotometry has been used to characterize AgNPs. The colloidal suspension of the AgNPs has been characterized by the UV-visible spectrophotometry within the range of 300$600 \mathrm{~nm}$ (Fig. 3(a)) [39, 44]. The absorption peak is observed between 400 and $500 \mathrm{~nm}$ in the UV-visible spectrophotometric graphs which are confirmed in the presence of the silver nanoparticles for all experimental runs [39, 44, 45]. Transmission Electron Microscopy (TEM) image of the AgNPs used for water purification could be seen in Fig. 3(b). SEM-EDX analysis results for AgNPs could be seen in Fig. 3(c)-(d).

The characterization of the synthesized GO-AgNPs via FTIR spectroscopy was depicted at Fig. 4(a). The increase in the intensity of the adsorption band at $3364 \mathrm{~cm}^{-1}$ of $\mathrm{OH}$ functional groups is originated from the sodium hydroxide

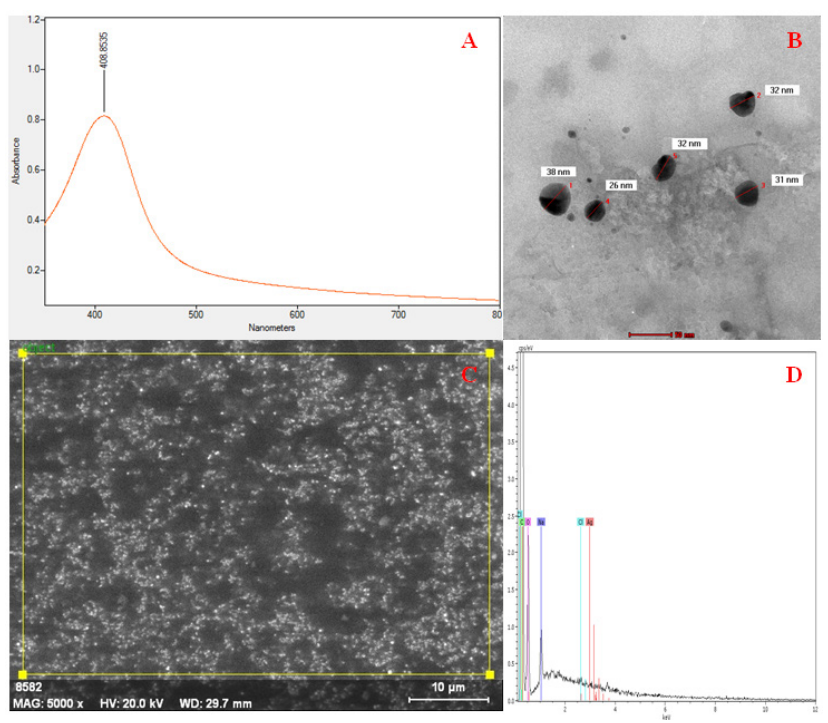

Fig. 3 Characterization of AgNPs (a) UV-VIS, (b) TEM analysis, (c) SEM image and (d) EDX analysis

used to adjust the $\mathrm{pH}$ of the silver nanoparticle synthesis. The intensity of the adsorption bands of the oxygenated functional groups of GO-AgNPs has lower value than the GO peaks in FTIR spectroscopy because of the existence of AgNP on the surface of GO and glucose reducer [45].

Bright spherical AgNPs particles and GO sheets as seen in AFM image demonstrates that a successful GO-AgNPs synthesis has been achieved. The average surface roughness of synthesized GO-AgNPs is found as $20.90 \mathrm{~nm}$ (Fig. 4(b)). As expected the (D-band intensity to G-band intensity) ID / IG ratios of the GO and GO-AgNPs are close to each other. Adhesion of silver nanoparticles on the graphene oxide layers cause defects in the material structure and because of these defects the ID / IG ratio has increased (Fig. 4(c)) [46].

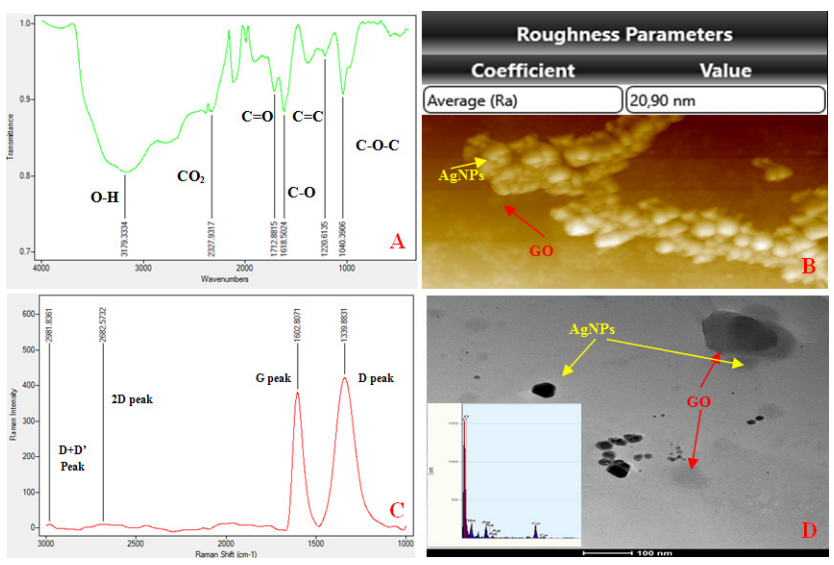

Fig. 4 Characterization of GO-AgNPs nanocomposites (a) FTIR, (b) AFM, (c) Raman spectroscopy and (d) TEM analysis 
The morphological analysis of synthesized GO-AgNPs was implemented with TEM analysis (Fig. 4(d)). Dark round spherical AgNPs spotsandsemi-transparent GO layerscan be easily distinguished via TEM images [41].

\subsection{Experimental procedure}

First, the dispersion of graphene oxide prepared with distilled water was stirred for 3 hours with a magnetic stirrer (Fig. 5(a)) and filtered to make sure that the filter paper was coated with graphene oxide (Fig. 5(b)). The raw water taken from the dam was divided into two parts. One half was used for control experiments by filtration with regular filter paper for physical, chemical and microbiological analysis of raw water. The other half on the other hand was filtered with a graphene-oxide coated filter paper (Cellulose acetate membran filter paper, 0.45 micron, 47 $\mathrm{mm}$ ) using a vacuum pump (Fig. 5(c)). Physical and chemical analyzes were applied to raw and treated water filtered through regular and graphene-oxide coated filter paper (Fig. 5(d)-(h)) [33].

Membrane filtration method was used for microbiological analysis. The raw water taken from the dam was passed through a regular and graphene oxide-coated filter with a pore size $0.45 \mu \mathrm{m}$ which is small enough to prevent the passage of microorganisms. Regular and graphene oxidecoated filter papers through which raw water was passed were incubated on selective media under conditions specified in the relevant standards (Fig. 5(i)).

\section{Water Purification Using GO}

The density of the synthesized graphene oxide powder was measured as $2.02 \mathrm{~g} / \mathrm{cm}^{3}$ with a Quantacrome multi-pycnometer. Then $0.1 \%$ to $0.8 \%$ (v/v) GO dispersions were prepared. Raw water and treated water analysis were performed for each experimental run.

\subsection{Physical and chemical performance of water purified by GO}

Despite the fact that the synthesized graphene oxide was washed with ethanol for several times at the last step of synthesis to remove manganese ions, it still lowered the $\mathrm{pH}$ value of raw water during the treatment process since it has lower $\mathrm{pH}$ value than raw water (Fig. 6(a)). Especially after $0.5 \%(\mathrm{v} / \mathrm{v}) \mathrm{GO}$ value by volume, it fell below the
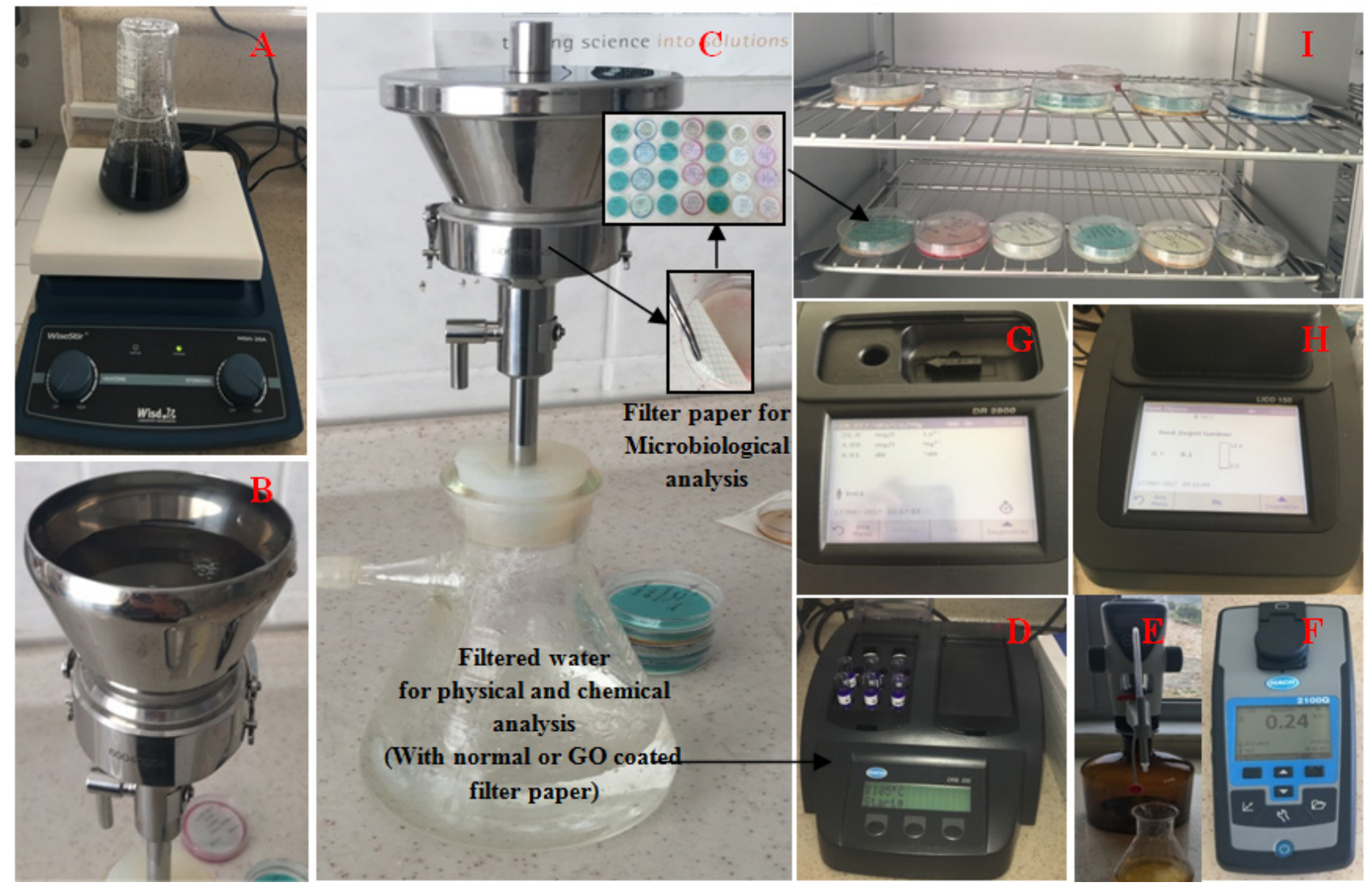

Fig. 5 Experimental procedure (a) GO dispersion, (b) Filtration, (c) Water purification set-up, (d) TOC analyzer, (e) titration set, (f) turbidimeter, (g) spectrophotometer, (h) Spectral colorimeter and (i) Incubator 
6.5 specified in TS 266 standard [35]. However, it is possible to use graphene oxide at high concentration by increasing the number of rinses. The $\mathrm{pH}$ value of graphene oxide samples synthesized is low because phosphoric acid and nitric acid were used in the synthesis of graphene, and hydrochloric acid was used to remove metal ions. Even though it is rinsed several times with ethanol and distilled water, it has a lower $\mathrm{pH}$ value than that of the raw water. However, the $\mathrm{pH}$ value can be increased by further increasing the number of rinses. Thus, $\mathrm{pH}$ adjustment can be made for the use of graphene oxide at high $0.5 \%(\mathrm{v} / \mathrm{v})$ concentrations. If high $\mathrm{pH}$ or alkalinity value is applied, it will reduce the success of the chlorination process and increase the cost.

The amount of alkalinity in raw water decreased as the amount of graphene oxide used in the filter system
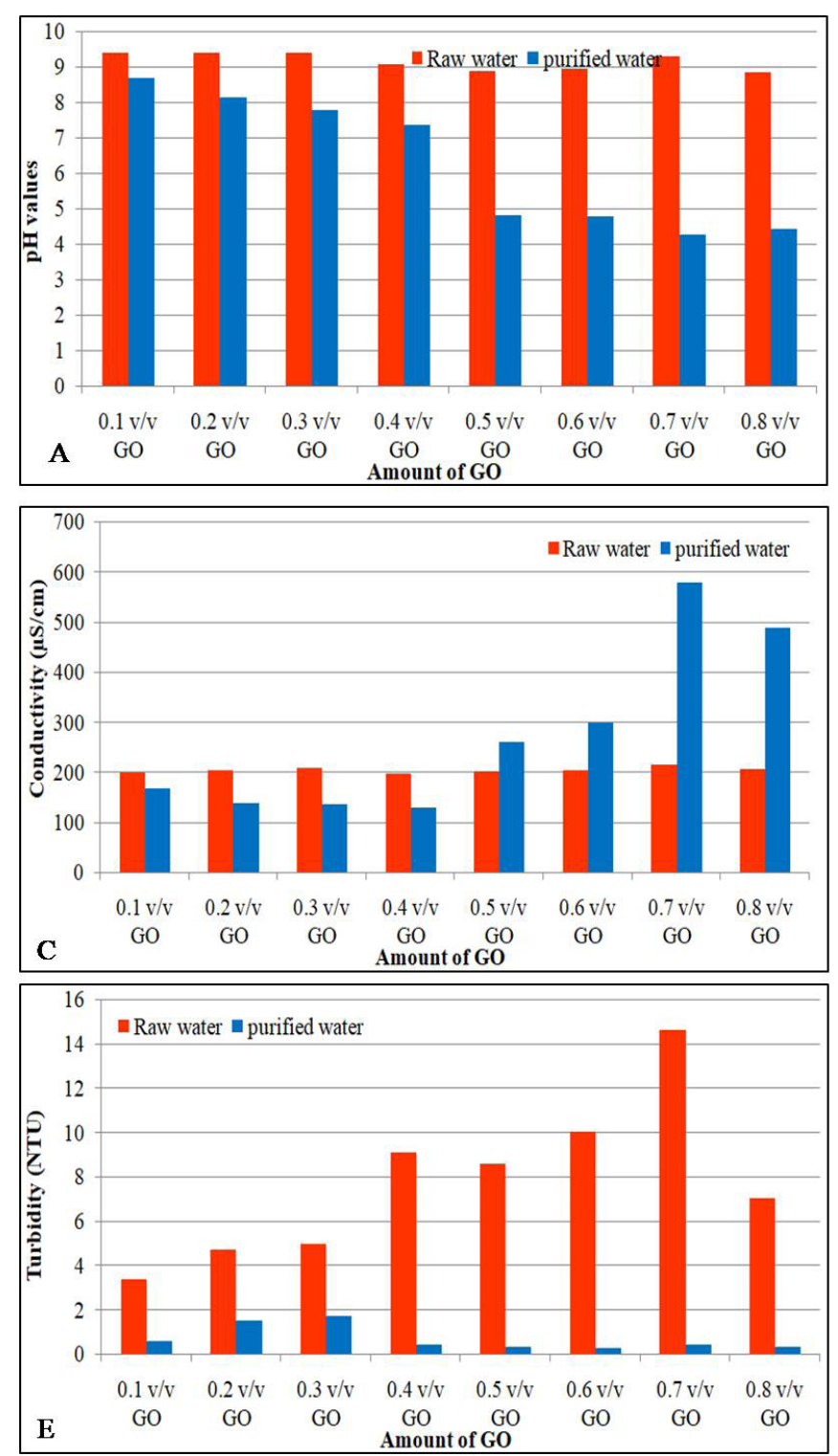

increased. In addition, high alkalinity is not harmful to human health, but it makes drinking water unpleasant. For this reason, it seems that graphene oxide will make the chlorination activity after nanomaterial more effectively. The alkalinity of raw water is between 120 and $140 \mathrm{mg} / \mathrm{L}$. Whereas the alkalinity of the treated water was determined as $0-120 \mathrm{mg} / \mathrm{L}$. These results show that water with the desired alkalinity can be obtained by graphene oxide filtration (Fig. 6(b)).

It was also observed that as the amount of graphene oxide used in the treatment increased, the conductivity increased while the amount of dissolved oxygen decreased (Fig. 6(c)). As the amount of graphene oxide used in the filtration process increases, the conductivity of the water increases. It is a well-known fact that the purity
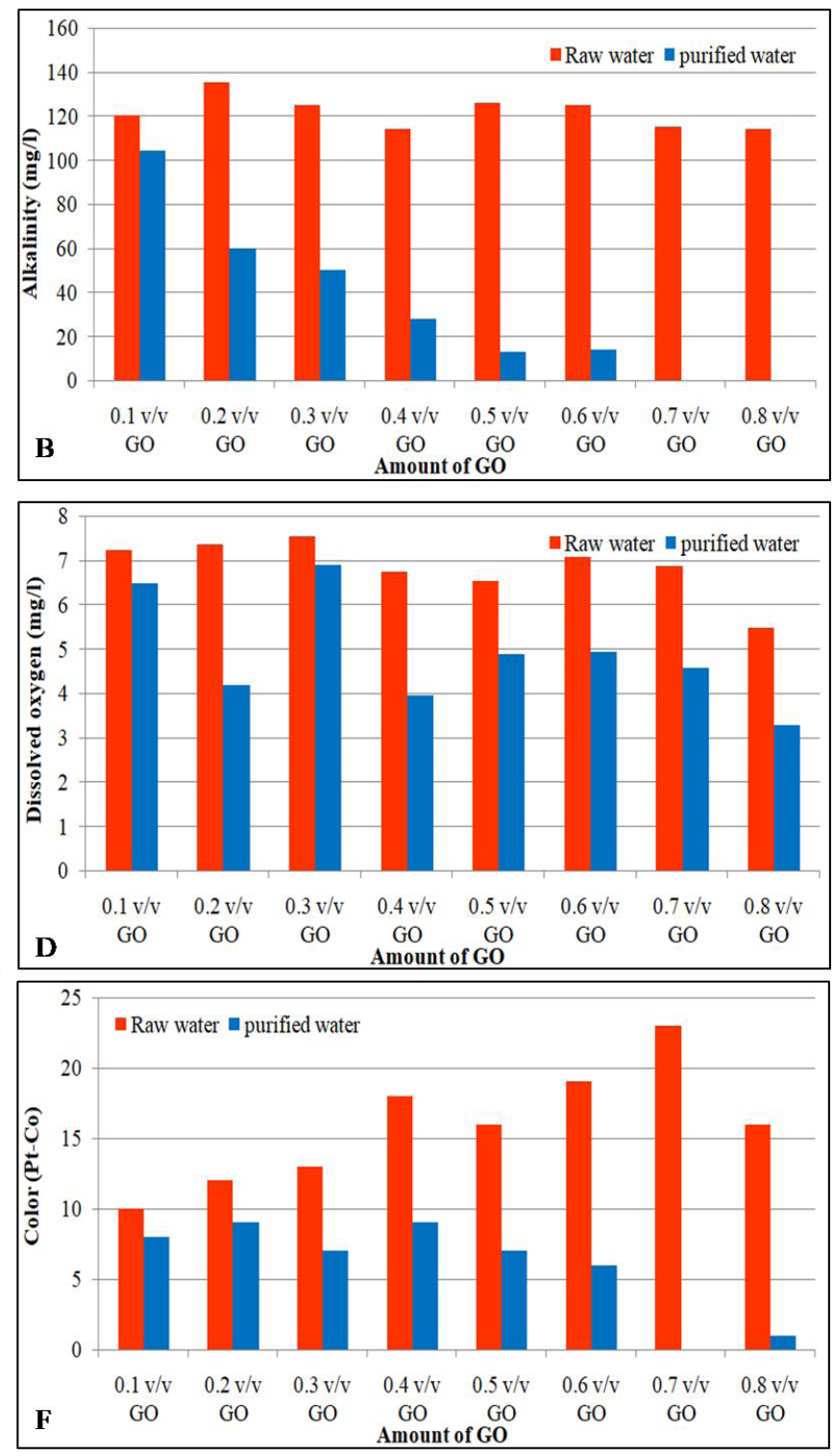

Fig. 6 Physical properties (a) pH, (b) Alkalinity, (c) Conductivity and (d) Dissolved oxygen, (e) Turbidity and (f) Color 
of water decreases as the conductivity increases. However, the conductivity of the treated water obtained in all experiments is within TS266 standards $(<2500 \mu \mathrm{S} / \mathrm{cm})$ [35]. It is known that the parameter that most affects the dissolved oxygen is the temperature and the high temperature decreases the dissolved oxygen concentration. Partial increase in the temperature of the water filtered by graphene oxide reduces the amount of dissolved oxygen in the water. Similarly, in all experiments, the amount of dissolved oxygen in the treated water is between 3 and 8 $\mathrm{mg} / \mathrm{L}$ as specified in TS266 (Fig. 6(d)) [35].

Two of the most important visual criteria for drinking water are turbidity and color criteria. Considering suspended solid (turbidity) and pollutants (color), it seems that graphene oxide is very successful in the treatment process (Fig. 6(e) and (f)). At $0.4 \%$ (v/v) GO and even at denser concentrations; it reduced the turbidity value of raw water which is higher than 10 NTU to below 1 NTU value specified in TS266 [35]. When raw and treated water analysis is considered, the Pt-Co scale of 10 for the raw water was found to decrease to 0 at $0.7 \%(\mathrm{v} / \mathrm{v}) \mathrm{GO}$ concentration by GO filtration.

When the removal of metals, metallic elements and chemicals in raw material by using graphene oxide was analyzed, it has been found that it was quite successful in the removal of iron, nitrite, manganese, calcium and magnesium (Fig. 7(a), (b), (d), (f) and (g)). Silica removal has been partly successful in the uses of intense graphene oxide (Fig. 7(h)). On the removal of nitrate and ammonia from water on the other hand, graphene oxide was not successful (Fig. 7(c) and (e)). It is foreseen that the use of nitric acid for the synthesis of graphene oxide might be accountable for this. No matter how well it is being washed, the ionization of $\mathrm{HNO}_{3}$ residues in graphene oxide sample as $\mathrm{NO}_{3}$ after they form dispersion with water might explain the high nitrate value in treated water.
When the removal of organic and inorganic pollutants from water by using graphene oxide was analyzed, graphene oxide seems to be quite successful in removing organic pollutants (with the use of GO at a concentration of $0.5 \% \mathrm{v} / \mathrm{v}$ or higher). On the other hand, on the removal of inorganic pollutants, there has been improvement only with the use of $0.6 \% \mathrm{v} / \mathrm{v}$ or higher concentrations of GO (Fig. 8). Graphene oxide is seen to be quite effective in removing water hardness (Fig. 9(a)). In all experiments soft water was obtained in TSE 266 standards [35]. When LSI values are analyzed, it is seen that water treated with graphene oxide at a concentration of $0.4 \%(\mathrm{v} / \mathrm{v})$ and higher concentration is highly corrosive (Fig. 9(b)). The maximum graphene oxide use in water treatment should be $0.3 \%$ (v/v) by volume in order not to have any corrosion problems.

\subsection{Microbiological performance of water purified by GO}

In this study, the inhibitions of very significant microorganisms threatening the quality of drinking water and human health such as E. coli fecal, E. faecalis, P. aeruginosa, S. aureus and E. coliform as well as S. typhimurium which causes serious health problems on humans, in water by filtration method with graphene oxide were determined. The inhibition effect on graphene oxide on $E$. faecalis, $S$. typhimurium and $P$. aeruginosa microorganisms was found to be quite high. In addition, the reproduction of all microorganisms, including total viable ones in water was completely inhibited, with $0.7 \%$ (v/v) graphene oxide use (Table 3). The results show that the number of total bacterial microorganisms after contact with GO coated membrane filter has reached zero values. Apparently, GO coated membrane filter showed strong antimicrobial activity against such microorganisms.

S. typhimurium, characterized by fever and abdominal pain, threatens human health with typhoid and at the

Table 3 Microbiological characteristics of raw water and drinking water purified by GO

\begin{tabular}{|c|c|c|c|c|c|c|c|c|c|c|}
\hline No. & $\begin{array}{l}\text { Quality criteria } \\
\text { (Feature) }\end{array}$ & $\begin{array}{c}\text { Raw } \\
\text { water }\end{array}$ & $\begin{array}{c}0.1 \% \text { GO } \\
(v / v)\end{array}$ & $\begin{array}{c}0.2 \% \text { GO } \\
(\mathrm{v} / \mathrm{v})\end{array}$ & $\begin{array}{c}0.3 \% \text { GO } \\
(v / v)\end{array}$ & $\begin{array}{c}0.4 \% \text { GO } \\
(\mathrm{v} / \mathrm{v})\end{array}$ & $\begin{array}{c}0.5 \% \text { GO } \\
(\mathrm{v} / \mathrm{v})\end{array}$ & $\begin{array}{c}0.6 \% \text { GO } \\
(\mathrm{v} / \mathrm{v})\end{array}$ & $\begin{array}{c}0.7 \% \text { GO } \\
(\mathrm{v} / \mathrm{v})\end{array}$ & $\begin{array}{c}0.8 \% \text { GO } \\
(\mathrm{v} / \mathrm{v})\end{array}$ \\
\hline M1 & Total viable count & $>100$ & $>100$ & $>100$ & 1 & $>100$ & 43 & $>100$ & 0 & 0 \\
\hline M2 & E-colifecal & $>100$ & $>100$ & $>100$ & 0 & 46 & 0 & $>100$ & 0 & 0 \\
\hline M3 & E. faecalis & $>100$ & 3 & 0 & 0 & 0 & 0 & 0 & 0 & 0 \\
\hline M4 & S. typhimurium & $>100$ & 0 & 0 & 0 & 0 & 0 & 0 & 0 & 0 \\
\hline M5 & P. aeruginosa & $>100$ & 40 & 0 & 0 & 0 & 0 & 0 & 0 & 0 \\
\hline M6 & S. aureus & $>100$ & $>100$ & 27 & 7 & 13 & 0 & 0 & 0 & 0 \\
\hline M7 & E. coliform & $>100$ & $>100$ & $>100$ & 0 & 33 & 1 & $>100$ & 0 & 0 \\
\hline
\end{tabular}



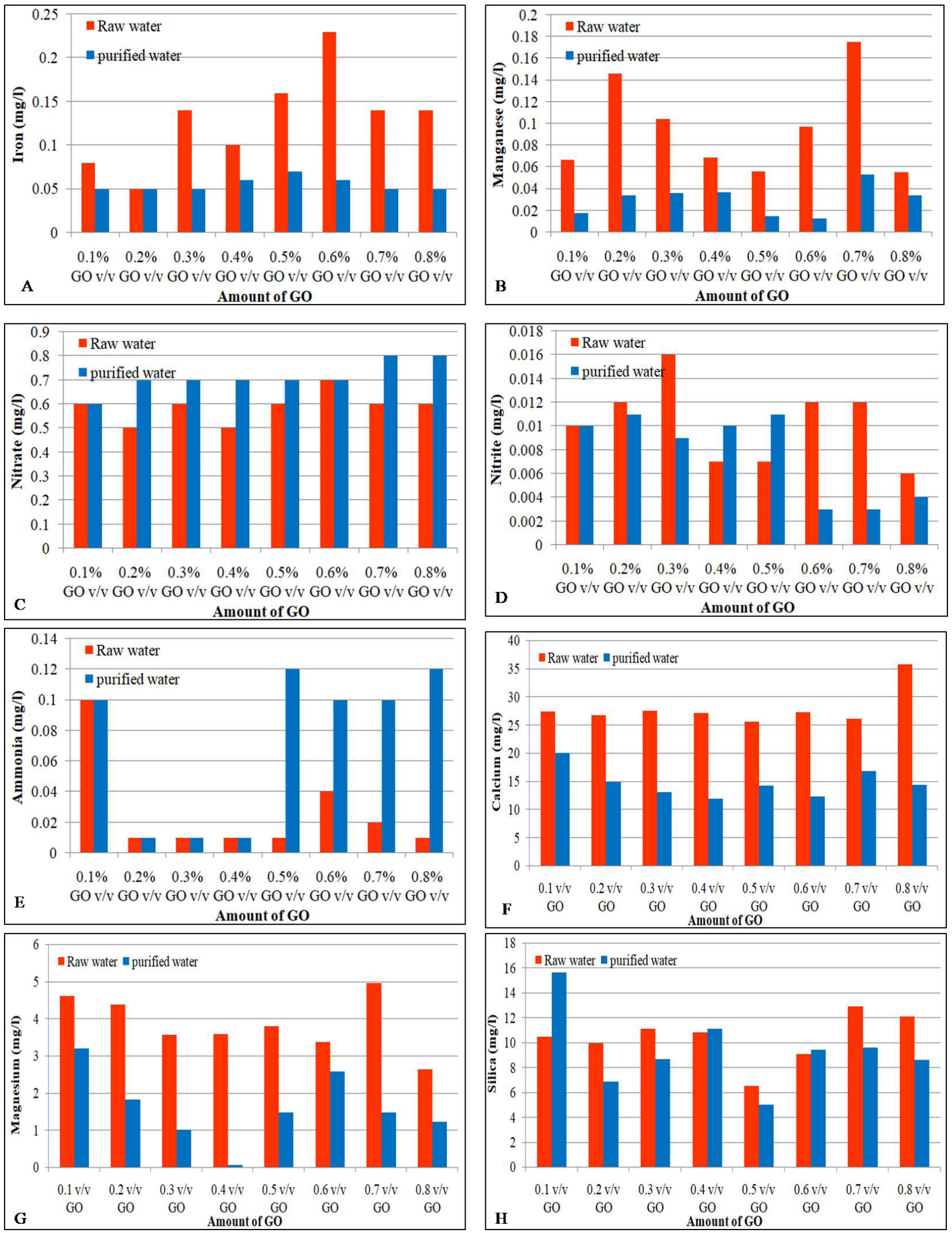

Fig. 7 Physical properties (a) iron, (b) manganese, (c) nitrate, (d) nitrite, (e) ammonia and (f) calcium, (g) magnesium and (h) silica 


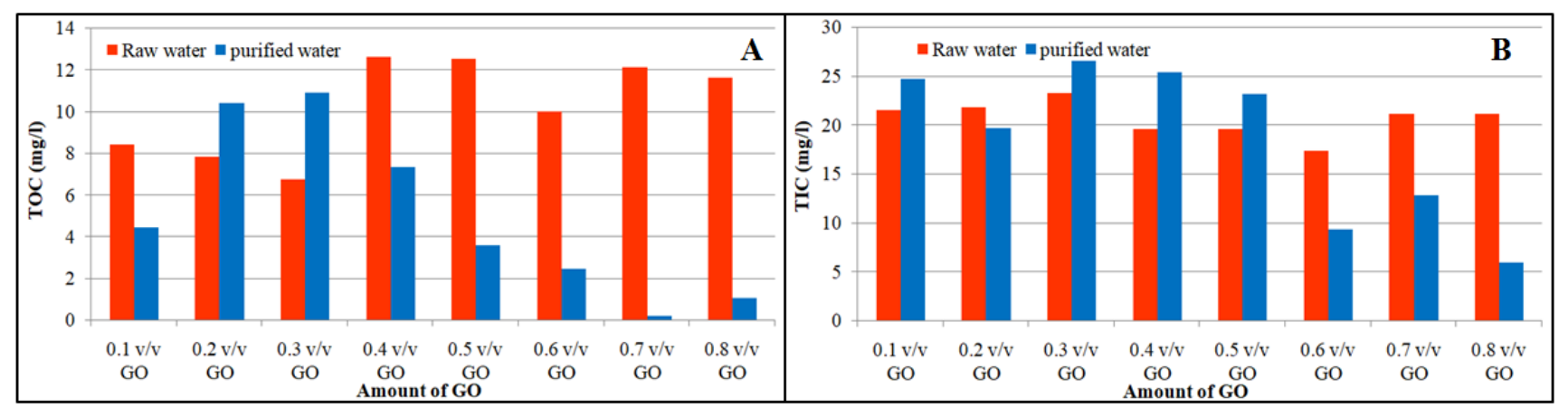

Fig. 8 Physical properties (a) TOC and (b) TIC

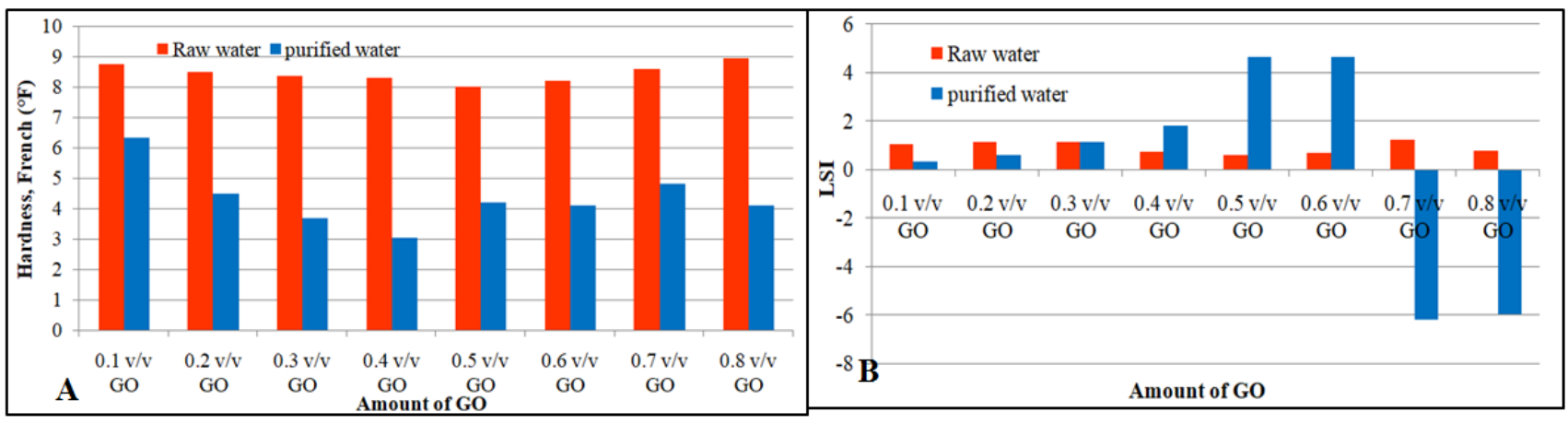

Fig. 9 Physical properties (a) hardness and (b) LSI

same time has a large host range that causes acute gastroenteritis in cattle and chickens [47]. As seen in Table 3, the number of $S$. typhimurium decreased to zero with very low GO solid liquid ratio (only $0.1 \%$, v/v). The applied graphene oxide-coated filter ensured that this microorganism was completely inhibited.

The development of resistance to existing antibiotics poses a serious challenge to global public health. There have been many structural alteration studies on antibiotics to struggle against this phenomenon [48]. Because of the potential antibacterial applications of graphene and graphene-based nanocomposites [49], conjugation of existing antibiotics with graphene-based materials is a promising solution to prevent antibacterial resistance $[50,51]$.

\section{Results and Discussions}

\subsection{Comparison between GO, AgNPs and GO-AgNPs in terms of water purification performance}

In this part; graphene oxide's water treatment performance was compared with other popular nanomaterials such as AgNPs and GO-Ag nanocomposites. While graphene oxide lowered the $\mathrm{pH}$ value during the raw water treatment, AgNPs and GO-Ag materials could not make any $\mathrm{pH}$ change in treated water. Similarly, while GO-Ag material reduced the alkalinity of raw water by only $15 \%$, the graphene oxide in the solid liquid ratio of $0.7 \%(\mathrm{v} / \mathrm{v})$ reduced the alkalinity of raw water by up to $99 \%$. GO, AgNPs and GO-Ag reduced the dissolved oxygen ratio in raw water while the conductivity of raw water increased by $169 \%$ with GO in the solid-liquid ratio of $0.7 \%$ (v/v).

It can be said that the conductivity increases with the increase of the ionized $\mathrm{COO}^{-}$groups in water as $\mathrm{GO}$ solid-liquid ratio increases. The color improvement rates of raw water reached the level of $94 \%$ at $0.8 \%$ (v/v) solid-liquid ratios. However, an improvement rate of $63 \%$ was achieved with AgNPs. In the filtration process using GO, while a maximum of $96 \%$ improvement in the turbidity value of the raw water was obtained, a $97 \%$ improvement rate was obtained with GO-Ag having very low particles (Fig. 10(a)).

At the removal of nitrite from raw water, an improvement rate of $75 \%$ was obtained at $0.6 \%$ (v/v) solid-liquid ratios. However, a $43 \%$ and $71 \%$ removal of nitrite from the raw water was achieved by filtration with AgNPs and GO-AgNPs nanocomposites (Fig. 10(b)).

Even though the graphene oxide was partially successful in iron, manganese and nitrate removal from raw water (iron and manganese only), there were improvements with GO-Ag use in the rates of $94 \%, 91 \%$ and $33 \%$, 


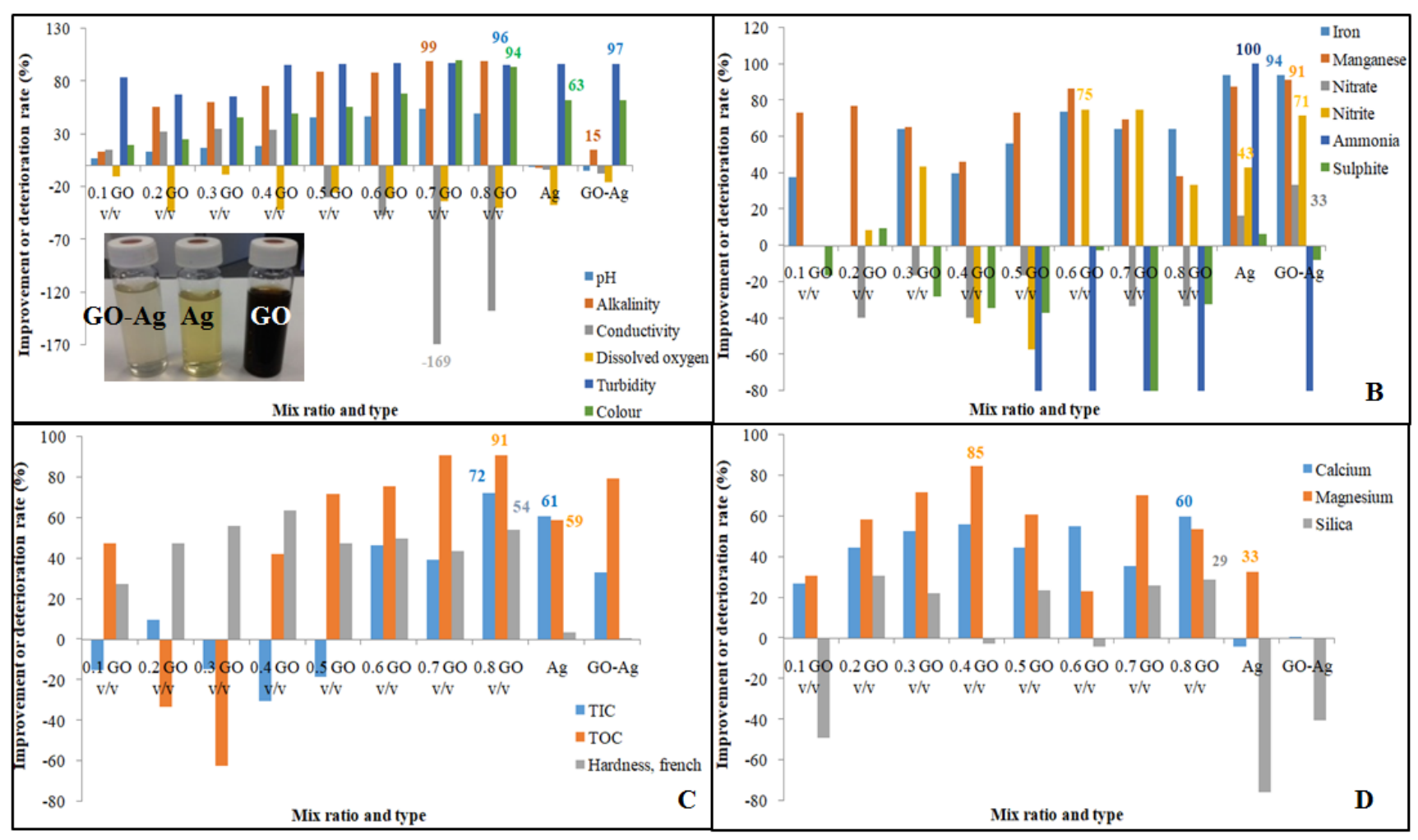

Fig. 10 Improvement or deterioration rate (\%) for physical properties

respectively. While GO and GO-AgNPs failed to remove ammonia from raw water, only AgNPs achieved a $100 \%$ improvement in ammonia removal (Fig. 10(b)).

At the removal of TIC, TOC and hardness from the raw water, the highest success rates were achieved with $72 \%$, $91 \%$ and $54 \%$, respectively, using GO at $0.8 \%$ (v/v) solid-liquid ratios. AgNPs and GO-AgNPs were not successful on the removal of the hardness from the raw water. However, on the removal of TIC and TOC from the raw water, silver has achieved a remarkable improvement by $61 \%$ and $59 \%$, respectively.

It was observed that graphene oxide was effective in the removal of calcium, magnesium and silica from raw water $(85 \%$ magnesium at $0.4 \%(\mathrm{v} / \mathrm{v})$ solid-liquid ratios, $60 \%$ calcium and $29 \%$ silica at $0.8 \%$ (v/v) solid-liquid ratios) while silver was effective only for magnesium removal (33\%) (Fig. 10(d)).

\subsection{Comparison between nano-materials vs. traditional methods in terms of water purification performance}

The traditional drinking water treatment is composed of the following stages: $\mathrm{KMnO}_{4}$ addition, pre-chlorination, ventilation, coagulation with aluminum hydroxy sulfate, poly electrolyte addition, clarification, filter basin, last chlorination and distribution warehouse.
In this section, raw water treatment results obtained by conventional method were compared with those of the methods using nanomaterials (Table 4).

As seen from the results, drinking water was obtained within the physical, chemical and microbiological standards by using AgNPs and GO-Ag. It seems that the use of graphene oxide in the raw water filtration is quite successful in the treatment of water (Table 4). It is highly corrosive with $-6.2 \mathrm{LDI}$ index. The high ratio of manganese can be solved by increasing the number of rinses during the synthesis of graphene oxide and by adjusting the $\mathrm{pH}$ with $\mathrm{KOH}$. Of course, it is also possible to produce drinking water suitable for physical and chemical standards by using only $0.1 \%(\mathrm{v} / \mathrm{v})$ of GO. However, using only $0.1 \%(\mathrm{v} / \mathrm{v}) \mathrm{GO}$ could not bring the microbiological characteristics to the desired level. For this reason, GO-Ag comes to the fore as the most successful and most promising nanomaterial (in terms of cost) in drinking water filtration. Microbiological analyses indicate that AgNPs having a very low solid-liquid ratio have very impressive antibacterial properties. The most remarkable result is the microbiological performance of GO-Ag nanocomposite containing low amount of silver and graphene oxide (Fig. 11(a)-(e)).

Compared with conventional methods, graphene oxide, silver nanoparticles, GO-Ag nanocomposites have been 
Table 4 Water purification performance comparison of the nano materials vs. traditional method

\begin{tabular}{|c|c|c|c|c|c|c|c|}
\hline No & Quality criteria & $\begin{array}{c}\text { Raw } \\
\text { water }\end{array}$ & $\begin{array}{c}\text { Traditional } \\
\text { method }\end{array}$ & $0.7 \%$ GO (v/v) & AgNPs & GO-AG & Standard \\
\hline $\mathrm{PC} 1$ & $\mathrm{pH}$ & 9.52 & 8.56 & 4.25 & 8.86 & 9.24 & $6.5-8.5$ \\
\hline $\mathrm{PC} 3$ & Conductivity, $\mu \mathrm{S} / \mathrm{cm}$ & 218.7 & 227.0 & 578 & 208.2 & 215.1 & $<2500$ \\
\hline PC5 & Turbidity, NTU & 1.39 & 0.25 & 0.41 & 0.29 & 0.26 & $0.4-1.0$ \\
\hline PC6 & Colour, Pt-Co & 7 & 2 & 1 & 6 & 6 & $1-20$ \\
\hline PC7 & Iron, $\mathrm{mg} / 1$ & 0.04 & 0.01 & 0.05 & 0.01 & 0.01 & $0.01-0.2$ \\
\hline PC8 & Manganese, mg/1 & 0.021 & 0.008 & 0.053 & 0.017 & 0.015 & $0.02-0.05$ \\
\hline $\mathrm{PC} 14$ & $\mathrm{TIC}, \mathrm{mg} / \mathrm{l}$ & 22.5 & 21.6 & 12.8 & 7.61 & 13 & $10-73$ \\
\hline PC15 & $\mathrm{TOC}, \mathrm{mg} / 1$ & 7.76 & 8.49 & 1.12 & 5.13 & 2.56 & $1-65$ \\
\hline $\mathrm{PC} 16$ & French hardness, $\mathrm{F}^{0}$ & 9.234 & 8.841 & 4.822 & 7.716 & 7.929 & $7.2-20$ \\
\hline PC18 & Calcium, mg/l & 28.3 & 29.4 & 16.8 & 26.6 & 25.4 & $<200$ \\
\hline PC19 & Magnesium, mg/l & 5.22 & 3.58 & 1.47 & 2.56 & 3.81 & $<50$ \\
\hline $\mathrm{PC} 21$ & LSI, $\mathrm{HO}_{3} \mathrm{mg} / 1$ & 1.6 & 1.4 & -6.2 & 0.68 & 1 & $-0.05<\mathrm{LSI}<2$ \\
\hline M1 & Total viable bacteria count & 9.52 & 0 & 0 & 100 & 0 & $<100$ adet $/ \mathrm{Ml}$ \\
\hline M2 & E-coliform fecal (MFC NKS) & 218.7 & 0 & 0 & 48 & 0 & 0 \\
\hline M3 & E.faecalis & 1.39 & 0 & 0 & 0 & 0 & 0 \\
\hline M4 & S. typhimurium & 7 & 0 & 0 & 0 & 0 & $0 / 100 \mathrm{ml}$ \\
\hline M5 & P. aeruginosa & 0.04 & 0 & 0 & 0 & 0 & $0 / 250 \mathrm{ml}$ \\
\hline M6 & S. aureus & 0.021 & 0 & 0 & 0 & 0 & $0 / 100 \mathrm{ml}$ \\
\hline M7 & E. coli & 22.5 & 0 & 0 & 11 & 0 & 0 \\
\hline
\end{tabular}

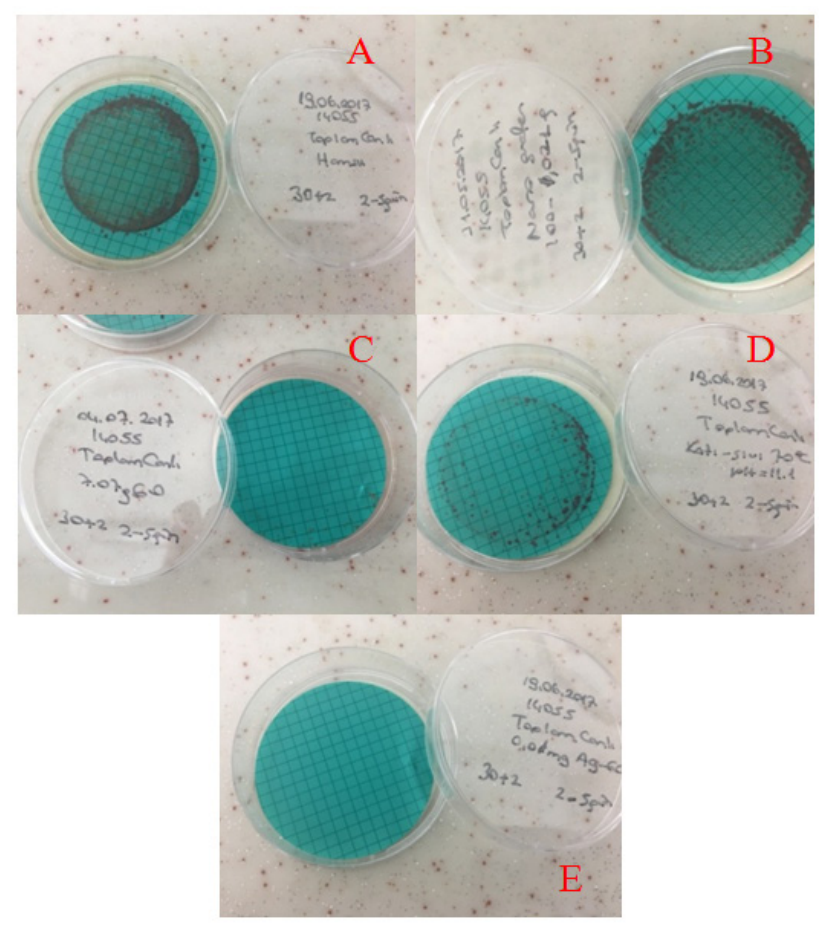

Fig. 11 Microbiological analyses for total viable counts (a) raw water, (b) GO $(0.1 \% \mathrm{v} / \mathrm{v})$, (c) GO $(0.7 \% \mathrm{v} / \mathrm{v})$, (d) $\mathrm{Ag}$ and (e) GO-Ag quite successful. While improvement rates of $82 \%, 71 \%$, $75 \%, 62 \%, 4 \%,-9 \%, 4 \%,-4 \%$ and $31 \%$ were obtained by conventional methods for turbidity, color, iron, manganese, TIC, TOC, hardness, calcium and magnesium removal, respectively; these improvement rates reached to the levels of $71 \%, 86 \%,-25 \%,-152 \%, 43 \%, 86 \%, 48 \%, 41 \%$ and $72 \%$ by GO-based filtration at the $0.7 \%$ (v/v) solid-liquid ratio. Improvement rates of $81 \%, 14 \%, 75 \%, 29 \%, 42 \%$, $67 \%, 14 \%, 10 \%$ and $27 \%$ were obtained for turbidity, color, iron, manganese, TIC, TOC, hardness, calcium and magnesium removal with GO-Ag Nanocomposites (Fig. 12). These results are noteworthy in that the nanomaterials can be used not only in a single step by itself alone but also at any stage of the treatment with conventional methods.

\section{Conclusions}

With the rapid growth of the world's population, water demand for drinking and general use is increasing steadily. As a result of environmental pollution, the water resources are getting polluted day by day and finding water resources in good quality and putting them into use are becoming 
limited. Even if suitable water resources are found, drinking water quality is adversely affected by the inconveniences in the treatment, distribution and storages. Prevention of this situation is possible by protection of water resources and their proper treatment, and continuous improvement of treatment processes. In this study, it was aimed to analyze the drinking water characteristics with a nanomaterial-based filtration system for the treatment of scarce water resources. In this study, the use of graphene oxide-coated filtration as drinking water treatment material at different solid-liquid ratios was analyzed in terms of physical, chemical and microbiological properties.

When compared to traditional method, there were improvements of $50 \%, 40.7 \%, 86.8 \%$ and $45.5 \%$ for color, TIC, TOC and hardness properties, respectively in water treatment by GO-based filtration with solid-liquid ratio of $0.7 \%$ (v/v). In water treatment with $\mathrm{GO}-\mathrm{Ag}$ based filtration, improvements in the rates of $39.8 \%, 69.8 \%, 10.3 \%$ and $28.6 \%$ were obtained for TIC, TOC, hardness and LSI value respectively compared to the conventional method. A very close turbidity value ( $0.26 \mathrm{NTU})$ has been obtained using GO-Ag based filtration according to the turbidity value (0.25 NTU) obtained by the traditional method. Both GO at $0.7 \%(\mathrm{v} / \mathrm{v})$ solid-liquid ratio and GO-Ag nanocomposites were successful in the inhibition of the total viable and the microorganisms such as E. colifecal, S. typhi, E. faecalis, P. aeruginosa, S. aureus, and E. coliform.

However, the most striking result of the study is the determination of the fact that graphene oxide silver nanoparticles and graphene oxide \& silver nanoparticles nanocomposites are very effective against Salmonella typhi microorganism.
Salmonella causes diseases by passing to people through contaminated water or food. It is particularly recommended to use them in industry such as fruit juice and milk industries where this microorganism can grow widely.

Both GO and GO-Ag has been successful in removing the turbidity, color, TOC, TIC, hardness, calcium and magnesium minerals. Only silver nanoparticles were successful in ammonia removal. The improvement rates in drinking water treatment obtained with all nanomaterials are very striking. In this study, raw water taken from the dam was treated with these nanomaterials. The improvement rates obtained in this study are an indication that these nanomaterials can be successfully used for the treatment of more problematic raw waters and wastewater.

The LSI value for the GO-based filtration method at $0.7 \%(\mathrm{v} / \mathrm{v})$ solid-liquid ratio, which is physically, chemically and microbiologically successful, is considerably smaller than the value of -2 and is out of the standards. This is an indication that the water filtered by the graphene oxide in these quantities is corrosive. However, water filtered with GO-Ag remained within the standards and was not corrosive. In this regard, it is recommended to use GO filtration with either GO-Ag nanocomposite or anti-corrosion materials.

Approximately $14.14 \mathrm{~g}$ of graphene oxide was used for the $0.7 \%(\mathrm{v} / \mathrm{v})$ graphene oxide dispersion. Taking into account the cost of chemicals used for graphene oxide, the cost of $0.7 \%(\mathrm{v} / \mathrm{v})$ graphene oxide dispersion is about $\$ 27.86$. The estimated cost for silver nanoparticle synthesis is approximately $\$ 0.06$. Silver nanoparticle \& graphene oxide nanocomposite synthesis' cost is

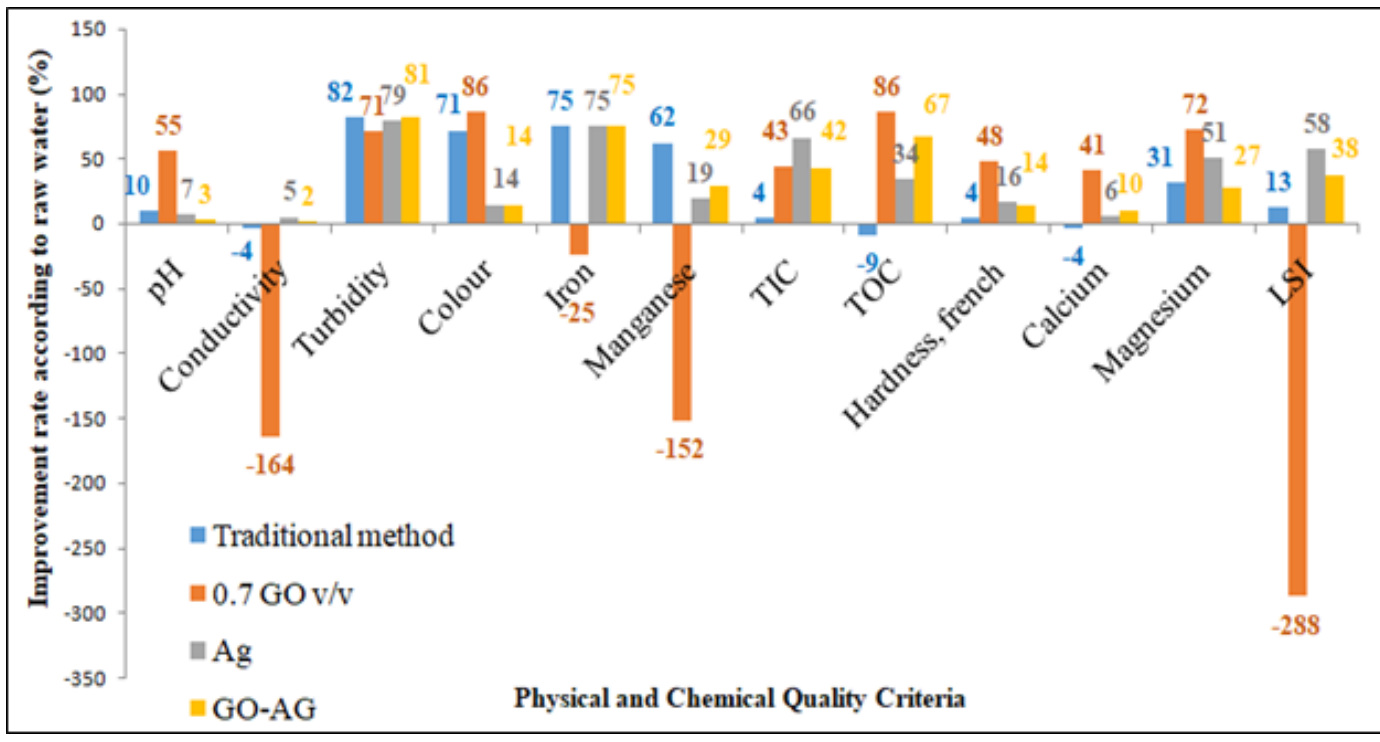

Fig. 12 Improvement or deterioration rate (\%) for physical properties 
Table 5 Calculation of the cost in USD / liter of treated water

\begin{tabular}{|c|c|c|c|c|c|c|}
\hline $\begin{array}{l}\text { Used } \\
\text { chemicals }\end{array}$ & $\begin{array}{l}\text { Amount of } \\
\text { the used } \\
\text { chemicals for } \\
\text { GO synthesis }\end{array}$ & $\begin{array}{c}\text { Cost of chemicals } \\
\text { for } 1 \mathrm{~g} \mathrm{GO} \text { synthesis } \\
\text { (\$) }\end{array}$ & $\begin{array}{l}\text { Amount of the } \\
\text { used chemicals } \\
\text { for AgNPs } \\
\text { dispersion } \\
\text { synthesis }\end{array}$ & $\begin{array}{c}\text { Cost of chemicals } \\
\text { for } 250 \mathrm{ml} \text { AgNPs } \\
\text { dispersion synthesis } \\
\text { (\$) }\end{array}$ & $\begin{array}{l}\text { Amount of the used } \\
\text { chemicals GO-Ag } \\
\text { nano composites } \\
\text { dispersion } \\
\text { synthesis }\end{array}$ & $\begin{array}{c}\text { Cost of chemicals } \\
\text { for } 250 \mathrm{ml} \text { GO-Ag } \\
\text { nano composites } \\
\text { dispersion synthesis } \\
\text { (\$) }\end{array}$ \\
\hline Graphite & $3 \mathrm{~g}$ & 0.1063 & N/A & N/A & $0.0060 \mathrm{~g}$ & 0.000213 \\
\hline $\mathrm{H}_{2} \mathrm{SO}_{4}$ & $69 \mathrm{ml}$ & 0.5920 & $\mathrm{~N} / \mathrm{A}$ & $\mathrm{N} / \mathrm{A}$ & $0.1380 \mathrm{ml}$ & 0.001184 \\
\hline $\mathrm{KMnO}_{4}$ & $9 \mathrm{~g}$ & 0.8197 & N/A & N/A & $0.0180 \mathrm{~g}$ & 0.001639 \\
\hline $\mathrm{H}_{2} \mathrm{O}_{2}$ & $10 \mathrm{ml}$ & 0.3806 & N/A & N/A & $0.0200 \mathrm{ml}$ & 0.000761 \\
\hline $\mathrm{HCl}$ & $5 \mathrm{ml}$ & 0.0693 & N/A & N/A & $0.0100 \mathrm{ml}$ & 0.000139 \\
\hline Starch & N/A & N/A & $0.2 \mathrm{~g}$ & 0.0519 & $0.2 \mathrm{~g}$ & 0.0519 \\
\hline $\mathrm{AgNO}_{3}$ & N/A & $\mathrm{N} / \mathrm{A}$ & $0.0017 \mathrm{~g}$ & 0.0039 & $0.0017 \mathrm{~g}$ & 0.0039 \\
\hline D-Glucose & N/A & N/A & $0.0036 \mathrm{~g}$ & 0.0004 & $0.0036 \mathrm{~g}$ & 0.0004 \\
\hline $\mathrm{NaOH}$ & N/A & N/A & $0.16 \mathrm{~g}$ & 0.0030 & $0.16 \mathrm{~g}$ & 0.0030 \\
\hline Total (\$) & & 1.97 & & 0.06 & & 0.063 \\
\hline $\begin{array}{l}\text { Cost of } \\
\text { Synthesized } \\
\text { Materials for } \\
5 \text { liter water } \\
\text { purification }\end{array}$ & & $\begin{array}{c}27.86 \$ / 0.7 \% \mathrm{GO} \\
(\mathrm{v} / \mathrm{v}) \\
(1.97 \mathrm{~g} / \$ * 14.14 \mathrm{~g})\end{array}$ & & $\begin{array}{c}0.06 \$ / 250 \mathrm{ml} \\
\mathrm{AgNPs}\end{array}$ & & $\begin{array}{c}0.063 \$ \text { / } 250 \mathrm{ml} \\
\text { GO-AgNPs }\end{array}$ \\
\hline $\begin{array}{l}\text { Cost in USD / } \\
\text { liter of treated } \\
\text { water }\end{array}$ & & $\begin{array}{c}5.57 \mathrm{USD} / \text { liter } \\
\text { for } 0.7 \% \mathrm{GO}(\mathrm{v} / \mathrm{v})\end{array}$ & & $\begin{array}{l}0.012 \mathrm{USD} / \text { liter } \\
\text { for AgNPs }\end{array}$ & & $\begin{array}{l}0.013 \mathrm{USD} / \text { liter } \\
\text { for GO-AgNPs }\end{array}$ \\
\hline
\end{tabular}

estimated at approximately $\$ 0.063$. The most remarkable point is that the composite with silver nanoparticle instead of graphene oxide alone, which is effective in water treatment, has both successful water treatment performance and cheaper cost. With these nanomaterials, about 2 cycles (about 5 liters of raw water) were successfully achieved. Cost in USD / liter of treated water has been calculated as 5.57, 0.012 and 0.013 for $0.7 \% \mathrm{GO}(\mathrm{v} / \mathrm{v})$, AgNPs and GO-Ag nanocomposites, respectively (Table 5).

\section{References}

[1] Hegab, H. M., Zou, L. "Graphene oxide-assisted membranes: Fabrication and potential applications in desalination and water purification", Journal of Membrane Science, 484, pp. 95-106, 2015. https://doi.org/10.1016/j.memsci.2015.03.011

[2] Ying, Y., Ying, W., Li, Q., Meng, D., Ren, G., Yan, R., Peng, X. "Recent advances of nanomaterial-based membrane for water purification", Applied Materials Today, 7, pp. 144-158. 2017. https://doi.org/10.1016/j.apmt.2017.02.010

[3] Figoli, A., Dorraji, M. S. S., Amani-Ghadim, A. R. "4 - Application of nanotechnology in drinking water purification", In: Grumezescu, A. M. (ed.) Water Purification, Academic Press, London, United Kingdom, 2017, pp. 119-167.

https://doi.org/10.1016/B978-0-12-804300-4.00004-6
Of course, if the silver nanoparticles \& graphene oxide nanocomposites synthesized in this study are coated with spin coater, spray pyrolysis or a different method on the filter paper, a more efficient and high amount of water treatment will be possible.

\section{Acknowledgement}

Authors thank to Çankırı Municipal, Water and Service Association.

[4] Fufă, M. O. M., Popescu, R. C., Grumezescu, A. M., Holban, A. M. "7 - Microorganisms: new trends in environment-friendly and energy-saving water purification.", In: Grumezescu, A. M. (ed.) Water Purification, Academic Press, London, United Kingdom, 2017, pp. 263-288.

https://doi.org/10.1016/B978-0-12-804300-4.00007-1

[5] Kunduru, K. R., Nazarkovsky, M., Farah, S., Pawar, R. P., Basu, A., Domb, A. J. "2 - Nanotechnology for water purification: applications of nanotechnology methods in wastewater treatment", In: Grumezescu, A. M. (ed.) Water Purification, Academic Press, London, United Kingdom, 2017, pp. 33-74. https://doi.org/10.1016/B978-0-12-804300-4.00002-2 
[6] Sarkar, S., Sarkar, A., Bhattacharjee, C. "10 - Nanotechnologybased membrane-separation process for drinking water purification", In: Grumezescu, A. M. (ed.) Water Purification, Academic Press, London, United Kingdom, 2017, pp. 355-389. https://doi.org/10.1016/B978-0-12-804300-4.00010-1

[7] Suthar, R. G., Gao, B. "3 - Nanotechnology for drinking water purification", In: Grumezescu, A. M. (ed.) Water Purification, Academic Press, London, United Kingdom, 2017, pp. 75-118. https://doi.org/10.1016/B978-0-12-804300-4.00003-4

[8] Aba, N. F. D., Chong, J. Y., Wang, B., Mattevi, C., Li, K. "Graphene oxide membranes on ceramic hollow fibers - Microstructural stability and nanofiltration performance", Journal of Membrane Science, 484, pp. 87-94, 2015.

https://doi.org/10.1016/j.memsci.2015.03.001

[9] Goh, K., Setiawan, L., Wei, L., Si, R., Fane, A. G., Wang, R., Chen, Y. "Graphene oxide as effective selective barriers on a hollow fiber membrane for water treatment process", Journal of Membrane Science, 474, pp. 244-253, 2015. https://doi.org/10.1016/j.memsci.2014.09.057

[10] Huang, L., Zhang, M., Li, C., Shi, G. "Graphene-Based Membranes for Molecular Separation", The Journal of Physical Chemistry Letters, 6(14), pp. 2806-2815, 2015. https://doi.org/10.1021/acs.jpclett.5b00914

[11] Sun, X.-F., Qin, J. Xia, P.-F., Guo, B.-B., Yang, C.-M., Song, C., Wang, S.-G. "Graphene oxide-silver nanoparticle membrane for biofouling control and water purification", Chemical Engineering Journal, 281, pp. 53-59, 2015. https://doi.org/10.1016/j.cej.2015.06.059

[12] Bryaskova, R., Georgieva, N., Pencheva, D., Todorova, Z., Lazarova, N., Kantardjiev, T. "Synthesis and characterization of hybrid materials with embedded silver nanoparticles and their application as antimicrobial matrices for waste water purification", Colloids and Surfaces A: Physicochemical and Engineering Aspects, 444, pp. 114-119, 2014.

https://doi.org/10.1016/j.colsurfa.2013.12.050

[13] Fernández, J. G., Almeida, C. A., Fernández-Baldo, M. A., Felici, E., Raba, J., Sanz, M. I. "Development of nitrocellulose membrane filters impregnated with different biosynthesized silver nanoparticles applied to water purification", Talanta, 146, pp. 237-243, 2016. https://doi.org/10.1016/j.talanta.2015.08.060

[14] Mirzajani, F., Motevalli, S. M., Jabbari, S., Ranaei Siadat, S. O., Sefidbakht, Y. "Recombinant Acetylcholinesterase purification and its interaction with silver nanoparticle", Protein Expression and Purification, 136, pp. 58-65, 2017. https://doi.org/10.1016/j.pep.2017.05.007

[15] Popescu, R. C., Fufă, M. O. M., Grumezescu, A. M., Holban, A. M. "12 - Nanostructurated membranes for the microbiological purification of drinking water", In: Grumezescu, A. M. (ed.) Water Purification, Academic Press, London, United Kingdom, 2017, pp. 421-446. https://doi.org/10.1016/B978-0-12-804300-4.00012-5

[16] Brobbey, K. J., Haapanen, J., Gunell, M., Mäkelä, J. M., Eerola, E., Toivakka, M., Saarinen, J. J. "One-step flame synthesis of silver nanoparticles for roll-to-roll production of antibacterial paper", Applied Surface Science, 420, pp. 558-565, 2017. https://doi.org/10.1016/j.apsusc.2017.05.143
[17] Morsi, R. E., Alsabagh, A. M., Nasr, S. A., Zaki, M. M. "Multifunctional nanocomposites of chitosan, silver nanoparticles, copper nanoparticles and carbon nanotubes for water treatment: Antimicrobial characteristics", International Journal of Biological Macromolecules, 97, pp. 264-269, 2017. https://doi.org/10.1016/j.ijbiomac.2017.01.032

[18] Yousefi, M., Dadashpour, M., Hejazi, M., Hasanzadeh, M., Behnam, B., de la Guardia, M., Shadjou, N., Mokhtarzadeh, A. "Anti-bacterial activity of graphene oxide as a new weapon nanomaterial to combat multidrug-resistance bacteria", Materials Science and Engineering: C, 74, pp. 568-581, 2017.

https://doi.org/10.1016/j.msec.2016.12.125

[19] Das, M. R., Sarma, R. K., Saikia, R., Kale, V. S., Shelke, M. V., Sengupta, P. "Synthesis of silver nanoparticles in an aqueous suspension of graphene oxide sheets and its antimicrobial activity", Colloids and Surfaces B: Biointerfaces, 83(1), pp. 16-22, 2011. https://doi.org/10.1016/j.colsurfb.2010.10.033

[20] Song, B., Zhang, C., Zeng, G., Gong, J., Chang, Y., Jiang, Y. "Antibacterial properties and mechanism of graphene oxide-silver nanocomposites as bactericidal agents for water disinfection", Archives of Biochemistry and Biophysics, 604, pp. 167-176, 2016.

https://doi.org/10.1016/j.abb.2016.04.018

[21] Faria, A. F., Liu, C., Xie, M., Perreault, F., Nghiem, L. D., Ma, J., Elimelech, M. "Thin-film composite forward osmosis membranes functionalized with graphene oxide-silver nanocomposites for biofouling control", Journal of Membrane Science, 525, pp. 146156, 2017.

https://doi.org/10.1016/j.memsci.2016.10.040

[22] Peng, J.-M., Lin, J.-C., Chen, Z.-Y., Wei, M.-C., Fu, Y.-X., Lu, S.-S., Yu, D.-S., Zhao, W. "Enhanced antimicrobial activities of silver-nanoparticle-decorated reduced graphene nanocomposites against oral pathogens", Materials Science and Engineering: C, 71, pp. 10-16, 2017.

https://doi.org/10.1016/j.msec.2016.09.070

[23] UNICEF, World Health Organization (WHO). "Progress on Sanitation and Drinking Water - 2015 Update and MDG Assessment", WHO Press, Geneva, Switzerland, pp. 1-90, 2015.

[24] Acharya, D., Singh, J. K., Adhikari, M., Gautam, S., Pandey, P., Dayal, V. "Association of water handling and child feeding practice with childhood diarrhoea in rural community of Southern Nepal", Journal of Infection and Public Health, 11(1), pp. 69-74, 2018. https://doi.org/10.1016/j.jiph.2017.04.007

[25] Komarulzaman, A., Smits, J., de Jong, E. "Clean water, sanitation and diarrhoea in Indonesia: Effects of household and community factors", Global Public Health, 12(9), pp. 1141-1155, 2017. https://doi.org/10.1080/17441692.2015.1127985

[26] Morgan, C., Bowling, M., Bartram, J., Kayser, G. L. "Water, sanitation, and hygiene in schools: Status and implications of low coverage in Ethiopia, Kenya, Mozambique, Rwanda, Uganda, and Zambia", International Journal of Hygiene and Environmental Health, 220(6), pp. 950-959, 2017. https://doi.org/10.1016/j.ijheh.2017.03.015 
[27] Ailes, E., Budge, P., Shankar, M., Collier, S., Brinton, W., Cronquist, A., Chen, M., Thornton, A., Beach, M. J., Brunkard, J. M. "Economic and Health Impacts Associated with a Salmonella Typhimurium Drinking Water Outbreak-Alamosa, CO, 2008", PLOS ONE, 8(3), e57439, 2013.

https://doi.org/10.1371/journal.pone.0057439

[28] Yang, Z., Yan, H., Yang, H., Li, H., Li, A., Cheng, R. "Flocculation performance and mechanism of graphene oxide for removal of various contaminants from water", Water Research, 47(9), pp. 3037-3046, 2013.

https://doi.org/10.1016/j.watres.2013.03.027

[29] Wang, J., Zhang, P., Liang, B., Liu, Y., Xu, T., Wang, L., Cao, B., Pan, K. "Graphene Oxide as an Effective Barrier on a Porous Nanofibrous Membrane for Water Treatment", Applied Materials \& Interfaces, 8(9), pp. 6211-6218, 2016. https://doi.org/10.1021/acsami.5b12723

[30] Yan, H., Wu, H., Li, K., Wang, Y., Tao, X., Yang, H., Li, A., Cheng, R. "Influence of the Surface Structure of Graphene Oxide on the Adsorption of Aromatic Organic Compounds from Water", Applied Materials \& Interfaces, 7(12), pp. 6690-6697, 2015. https://doi.org/10.1021/acsami.5b00053

[31] Henriques, B., Gonçalves, G., Emami, N., Pereira, E., Vila, M., Marques, P. A. A. P. "Optimized graphene oxide foam with enhanced performance and high selectivity for mercury removal from water", Journal of Hazardous Materials, 301, pp. 453-461, 2016.

https://doi.org/10.1016/j.jhazmat.2015.09.028

[32] Aboubaraka, A. E., Aboelfetoh, E. F., Ebeid, E.-Z. M. "Coagulation effectiveness of graphene oxide for the removal of turbidity from raw surface water", Chemosphere, 181, pp. 738-746, 2017. https://doi.org/10.1016/j.chemosphere.2017.04.137

[33] Ghosh, S., Vandana, V. "Nano-structured mesoporous silica / silver composite: Synthesis, characterization and targeted application towards water purification", Materials Research Bulletin, 88, pp. 291-300, 2017. https://doi.org/10.1016/j.materresbull.2016.12.044

[34] Kennedy, A. J., Chappell, M. A., Bednar, A. J., Ryan, A. C., Laird, J. G., Stanley, J. K., Steevens, J. A. "Impact of Organic Carbon on the Stability and Toxicity of Fresh and Stored Silver Nanoparticles", Environmental Science \& Technology, 46(19), pp. 10772-10780, 2012. https://doi.org/10.1021/es302322ył

[35] Türk Standardlari Enstitüsü (TSE) (Turkish Standards Institution) "Sular - İnsanî tüketim amaçlı sular", (Water Intended for Human Consumption), TS 266, TSE, Ankara, Turkey, p. 20, 2005. (in Turkish)

[36] Chen, J., Li, Y., Huang, L., Li, C., Shi, G. "High-yield preparation of graphene oxide from small graphite flakes via an improved Hummers method with a simple purification process", Carbon, 81, pp. 826-834, 2015.

https://doi.org/10.1016/j.carbon.2014.10.033

[37] Şimşek, B., Ultav, G., Korucu, H., Yartaş1, A. "Improvement of the Graphene Oxide Dispersion Properties with the Use of TOPSIS Based Taguchi Application", Periodica Polytechnica Chemical Engineering, 62(3), pp. 323-335, 2018.

https://doi.org/10.3311/PPch.11412
[38] Korucu, H., Şimşek, B., Yartaşı, A. "A TOPSIS-Based Taguchi Design to Investigate Optimum Mixture Proportions of Graphene Oxide Powder Synthesized by Hummers Method", Arabian Journal for Science and Engineering, 2018. https://doi.org/10.1007/s13369-018-3184-4

[39] Karhan, Ö., Ceran, Ö. B., Şara, O. N., Şimşek, B. "Response Surface Methodology Based Desirability Function Approach to Investigate Optimal Mixture Ratio of Silver Nanoparticles Synthesis Process", Industrial \& Engineering Chemistry Research, 56(28), pp. 8180-8189, 2017. https://doi.org/10.1021/acs.iecr.7b01150

[40] Kavinkumar, T., Varunkumar, K., Ravikumar, V., Manivannan, S. "Anticancer activity of graphene oxide-reduced graphene oxide-silver nanoparticle composites", Journal of Colloid and Interface Science, 505, pp. 1125-1133, 2017. https://doi.org/10.1016/j.jcis.2017.07.002

[41] Thapa, R. K., Kim, J. H., Jeong, J.-H., Shin, B. S., Choi, H.-G., Yong, C. S., Kim, J. O. "Silver nanoparticle-embedded graphene oxide-methotrexate for targeted cancer treatment", Colloids and Surfaces B: Biointerfaces, 153, pp. 95-103, 2017. https://oi.org/10.1016/j.colsurfb.2017.02.012

[42] Guerrero-Contreras, J., Caballero-Briones, F. "Graphene oxide powders with different oxidation degree, prepared by synthesis variations of the Hummers method", Materials Chemistry and Physics, 153, pp. 209-220, 2015. https://doi.org/10.1016/j.matchemphys.2015.01.005

[43] Zaaba, N. I., Foo, K. L., Hashim, U., Tan, S. J., Liu, W.-W., Voon, C. H. "Synthesis of Graphene Oxide using Modified Hummers Method: Solvent Influence", Procedia Engineering, 184, pp. 469-477, 2017. https://doi.org/10.1016/j.proeng.2017.04.118

[44] Biswas, S., Mulaba-Bafubiandi, A. F. "Optimization of process variables for the biosynthesis of silver nanoparticles by Aspergillus wentii using statistical experimental design", Advances in Natural Sciences: Nanoscience and Nanotechnology, 7(4), 045005, 2016. https://doi.org/10.1088/2043-6262/7/4/045005

[45] Chook, S. W., Chia, C. H., Zakaria, S., Ayob, M. K., Chee, K. L., Huang, N. M., Neoh, H. M., Lim, H. N., Jamal, R., Rahman, R. M. F. R. A. "Antibacterial performance of Ag nanoparticles and AgGO nanocomposites prepared via rapid microwave-assisted synthesis method", Nanoscale Research Letters, 7, 541, 2012. https://doi.org/10.1186/1556-276x-7-541

[46] Hui, K. S., Hui, K. N., Dinh, D. A., Tsang., C. H., Cho, Y. R., Zhou, W., Hong, X., Chun, H.-H. "Green synthesis of dimension-controlled silver nanoparticle-graphene oxide with in situ ultrasonication", Acta Materialia, 64, pp. 326-332, 2014. https://doi.org/10.1016/j.actamat.2013.10.045

[47] Mutreja, R., Jariyal, M., Pathania, P., Sharma, A., Sahoo, D. K., Suri, C. R. "Novel surface antigen based impedimetricimmunosensor for detection of Salmonella typhimurium in water and juice samples", Biosensors and Bioelectronics, 85, pp. 707-713, 2016.

https://doi.org/10.1016/j.bios.2016.05.079 
[48] Some, S., Ho, S.-M., Dua, P., Hwang, E., Shin, Y. H., Yoo, H. J., Kang, J.-S., Lee, D.-K., Lee, H. "Dual Functions of Highly Potent Graphene Derivative-Poly-L-Lysine Composites To Inhibit Bacteria and Support Human Cells", ACS Nano, 6(8), pp. 71517161, 2012.

https://doi.org/10.1021/nn302215y

[49] Akhavan, O., Ghaderi, E. "Toxicity of Graphene and Graphene Oxide Nanowalls Against Bacteria" ACS Nano, 4(10), pp. 57315736, 2010.

https://oi.org/10.1021/nn101390x
[50] Mishra, R. K., Segal, E., Lipovsky, A., Natan, M., Banin, E., Gedanken, A. "New Life for an Old Antibiotic", ACS Applied Materials \& Interfaces, 7(13), pp. 7324-7333, 2015. https://doi.org/10.1021/acsami.5b00563

[51] Omidi, S., Kakanejadifard, A., Azarbani, F. "Noncovalent functionalization of graphene oxide and reduced graphene oxide with Schiff bases as antibacterial agents", Journal of Molecular Liquids, 242, pp. 812-821, 2017.

https://doi.org/10.1016/j.molliq.2017.07.074 